A RCHIWA, BIBLIOTEKI

I MUZEA KOŚCIELNE 109 (2018)

https://doi.org/10.31743/abmk.2018.109.15

PIOTR RACHWAŁ* - LUBLIN

\title{
ZASÓB KSIĄG METRYKALNYCH W ARCHIWACH PARAFII RZYMSKOKATOLICKICH LUBELSZCZYZNY. CZĘŚĆ I**
}

Prezentowany tekst rozpoczyna cykl artykułów, w których omówiony zostanie zasób ksiąg metrykalnych przechowywanych w archiwach parafialnych Lubelszczyzny (zob. Aneks). Akcja inwentaryzacji metryk prowadzona była w latach 2012-2015, w ramach szerszego projektu badawczego ${ }^{1}$. Zakładał on, obok wspomnianej inwentaryzacji metryk, ich digitalizację oraz badania nad demografią Lubelszczyzny w XVI-XIX wieku. Kwerendą objęto w sumie 60 parafii (mapa 1.) $)^{2}$. W kolejności alfabetycznej są to parafie: Abramowice pw. św. Jakuba Apostoła, Baranów pw. św. Jana Chrzciciela, Bełżyce pw. Nawrócenia św. Pawła Apostoła, Biskupice pw. św. Stanisława BM, Bychawa pw. św. Jana Chrzciciela i św. Franciszka z Asyżu, Bychawka pw. Wszystkich Świętych, Bystrzyca pw. Wniebowzięcia NMP, Chodel pw. Trójcy Świętej i Narodzenia NMP, Czemierniki pw. św. Stanisława BM, Czerniejów pw. św. Wawrzyńca, Częstoborowice pw. śś. Apostołów Piotra i Pawła, Dys pw. św. Jana Chrzciciela, Fajsławice pw. św. Jana Nepomucena, Firlej pw. Przemienienia Pańskiego, Garbów pw. Przemienienia Pańskiego, Gołąb pw. św. Floriana i św. Katarzyny, Kamionka pw. śś. Apostołów Piotra i Pawła, Karczmiska pw. św. Waw-

* Piotr Rachwał - dr historii; adiunkt w Instytucie Historii KUL; e-mail: piotrach@kul.pl

** Wyrazy wdzięczności składam Metropolicie Lubelskiemu, JE. Abp. prof. dr hab. Stanisławowi Budzikowi, za umożliwienie dostępu do archiwów parafialnych. Dziękuję także wszystkim księżom proboszczom wspomnianych parafii, którzy wykazali dużą cierpliwość $\mathrm{w}$ trakcie kwerendy naukowej, okazali życzliwość i gościnność. Gorące podziękowania kieruję również w stronę dyrektora Archiwum Archidiecezjalnego Lubelskiego ks. dr hab. Jarosława Marczewskiego, prof. KUL, za wsparcie i osobiste zaangażowanie w realizację projektu.

${ }^{1}$ Badania realizowane w ramach „Narodowego Programu Rozwoju Humanistyki” w latach 2012-2017 (nr 11.H 12050581 - Ludność historycznego powiatu lubelskiego w latach 1582 (1594)1900 w świetle rejestracji metrykalnej), finansowanego przez Ministerstwo Nauki i Szkolnictwa Wyższego.

${ }^{2} \mathrm{O}$ kryteriach doboru terytorialnego zob. P. Rachwał, Staropolskie księgi metrykalne $w$ archiwach parafialnych archidiecezji lubelskiej, „Kwartalnik Historii Kultury Materialnej” (dalej: Kw.HKM), 63 (2015) nr 4, s. 585-601. 
rzyńca, Kazimierz Dolny pw. św. Jana Chrzciciela i św. Bartłomieja Apostoła, Kiełczewice pw. Trójcy Przenajświętszej i Nawiedzenia NMP, Kijany pw. św. Anny, Klementowice pw. św. Klemensa i św. Małgorzaty, Kluczkowice pw. Świętej Trójcy, Konopnica pw. Wniebowzięcia NMP i św. Katarzyny Aleksandryjskiej, Końskowola pw. Znalezienia Krzyża Świętego i św. Andrzeja Apostoła, Krasienin pw. Narodzenia NMP i św. Sebastiana, Krężnica Jara pw. św. Floriana, Krzczonów pw. Wniebowzięcia NMP, Kurów pw. Narodzenia NMP i św. Michała Archanioła, Lubartów pw. św. Anny, Lublin pw. św. Jana Chrzciciela i św. Jana Ewangelisty, Lublin pw. św. Mikołaja (na Czwartku), Lublin pw. św. Marcina (dawniej: Zemborzyce), Lancuchów pw. św. Jana Chrzciciela, Łęczna pw. św. Marii Magdaleny, Luszczów pw. św. Barbary, Markuszów pw. św. Józefa, Matczyn pw. Wniebowzięcia NMP, Mełgiew pw. św. Wita, Michów pw. Wniebowzięcia NMP, Milejów pw. Wniebowzięcia NMP, Nałęczów pw. św. Jana Chrzciciela (dawna p. Bochotnica), Niedrzwica Kościelna pw. św. Bartłomieja Apostoła, Opole Lubelskie pw. Wniebowzięcia NMP, Ostrów Lubelski pw. Niepokalanego Poczęcia NMP, Parczew pw. św. Jana Chrzciciela, Piaski pw. Podwyższenia Krzyża Świętego, Piotrawin pw. św. Tomasza Apostoła i św. Stanisława BM, Puchaczów pw. Wniebowzięcia NMP, Pulawy pw. św. Józefa (dawniej: Włostowice), Ratoszyn pw. św. Macieja Apostoła i św. Katarzyny, Rudno pw. Podwyższenia Krzyża Świętego, Serniki pw. św. Marii Magdaleny, Targowisko pw. św. Tomasza Becketa, Wąwolnica pw. św. Wojciecha BM, Wilkołaz pw. św. Jana Chrzciciela, Wilków pw. św. Floriana i św. Urszuli, Wojciechów pw. św. Teodora, Wysokie pw. św. Michała Archanioła, Żyrzyn pw. śs. Apostołów Piotra i Pawła.

Inwentaryzacja w wyżej wymienionych archiwach parafialnych objęła księgi metrykalne z okresu staropolskiego - prowadzone według formularza trydenckie$\mathrm{go}^{3}$, tzw. księgi austriackie wypełniane według przepisów zawartych w patencie cesarskim Józefa II z 20 lutego 1784 r. ${ }^{4} \mathrm{Na}$ omawianym obszarze obowiązek prowadzenia przez proboszczów rejestracji metrykalnej według rubrykowanych formularzy obowiązywały od 1797 r. do 15 sierpnia 1810 r., kiedy to w Galicji Zachodniej wszedł w życie Kodeks Cywilny Napoleona. Urzędnicy stanu cywilnego, którymi w praktyce byli duchowni, zostali zobowiązani do prowadzenia ksiąg w dwóch jednobrzmiących egzemplarzach. Unikat pozostawał w parafii, duplikat miano odsyłać do właściwego sądu pokoju. Pewne zmiany w zakresie rejestracji zaszły wraz z wprowadzeniem Kodeksu Cywilnego Królestwa Polskiego ${ }^{5}$. Metryki prowadzone zgodnie $\mathrm{z}$ tymi przepisami prowadzono jeszcze na początku XX w.

${ }^{3}$ Szerzej zob. P. Rachwał, Historyczna rejestracja metrykalne $w$ archiwach parafialnych w Lubelskiem, w: Retrospekcja i ochrona dziedzictwa kulturowego, red. S. Kowalska, D. Wańka, Poznań-Kalisz 2015, s. 150-153.

${ }^{4}$ Więcej zob. P. Rachwał, Księgi metrykalne z czasów zaboru austriackiego w archiwach parafialnych w Lubelskiem - regulacje prawne, stan zachowania, ,Rocznik Lubelskiego Towarzystwa Genealogicznego", 6 (2014/2015) s. 306-314.

${ }^{5} \mathrm{O}$ przepisach rejestracji ruchu naturalnego obrządku rzymskokatolickiego w Królestwie Polskim zob. J. Gawrysiakowa, Grupy wyznaniowe ludności w Lubelskiem w XIX wieku, Lublin 1992, s. $22-24$. 
Prace inwentaryzacyjne objęły i te księgi, przy czym cezurę czasową stanowi 31 grudzień $1900 \mathrm{r}$. Jednostki archiwalne rozpoczynające się od metryk z datą późniejszą, nie zostały już skatalogowane.

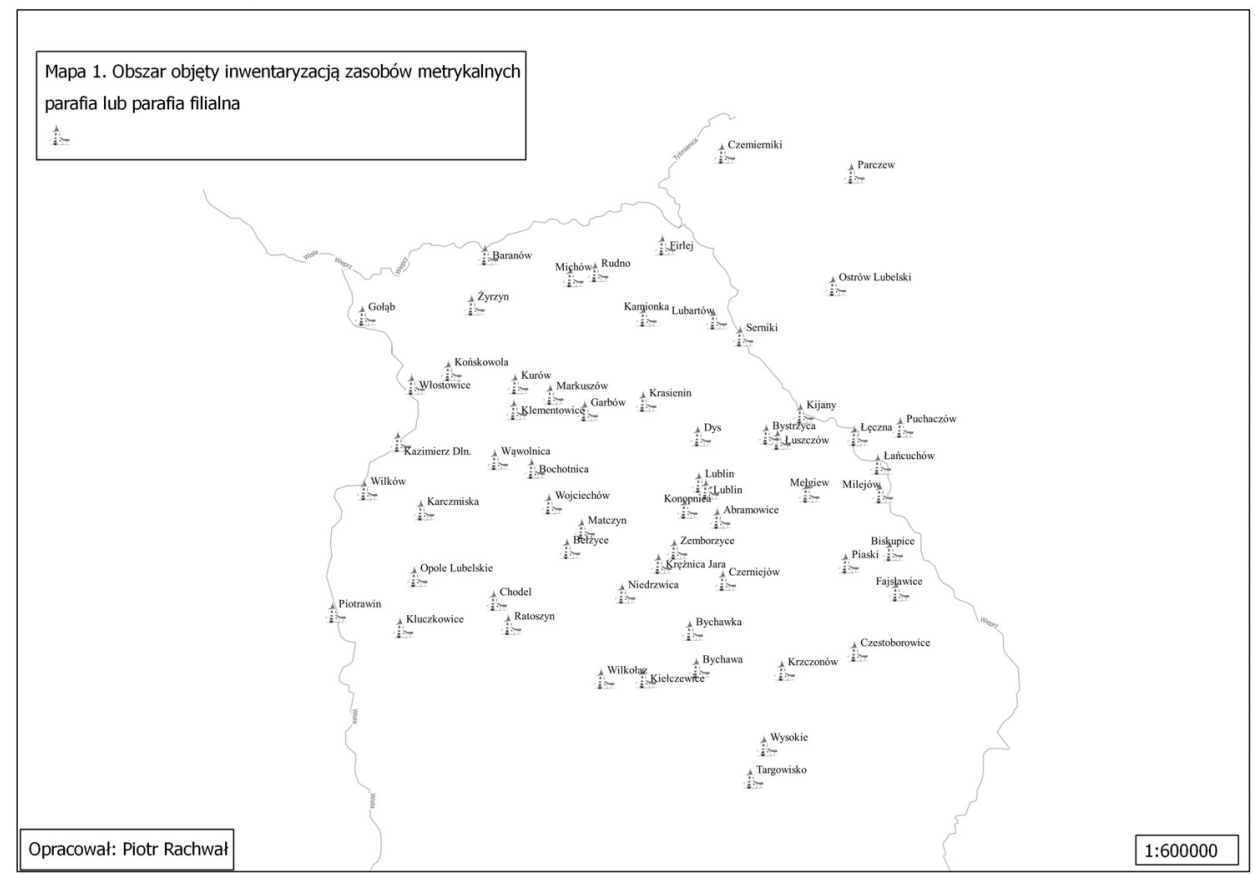

\section{Wcześniejsze próby inwentaryzacji zasobu}

Na potrzebę orientacji w zasobie ksiąg metrykalnych w szerszym ujęciu terytorialnym, zwrócono uwagę jeszcze przed pierwszą wojną światową. Jednym z pionierów był wybitny historyk Franciszek Bujak. Rozpoczął on indywidualne zbieranie informacji o zasobach oraz stanie zachowania metryk wybranych parafii galicyjskich, sporządzał także wyciągi statystyczne. Po zakończeniu wojny zaczął gromadzić dane o zawartości archiwów parafialnych i diecezjalnych. Posługiwał się przy tym ankietą oraz bezpośrednim przeszukiwaniem zasobów. Ważnym wydarzeniem okazał się Powszechny Zjazd Historyków Polskich w 1935 r. F. Bujak wygłosił wówczas referat, w którym zwrócił uwagę na pilną potrzebę opracowania historii zaludnienia ziem polskich. Pierwszym krokiem do tego celu miała być inwentaryzacja archiwów pod kątem przydatnych źródeł, w tym przede wszystkim rejestracji metrykalnej. Starania podjęte w odpowiedzi na wytyczone postulaty skutkowały zebraniem informacji dotyczących ksiąg metrykalnych z części diecezji krakowskiej i kilku innych zbiorów archiwalnych. W sumie jednak efekty całej akcji nie przyniosły oczekiwanych rezultatów ${ }^{6}$.

${ }^{6} \mathrm{~S}$. Hoszowski, Dynamika rozwoju zaludnienia Polski w epoce feudalnej (X-XVIII w.), „Roczniki Dziejów Społecznych i Gospodarczych” (dalej: RDSG), 13 (1951) s. 160-161; S. Hoszowski, 
Do prekursorów, którzy podjęli starania w kierunku inwentaryzacji ksiąg metrykalnych Lubelszczyzny należy zaliczyć Henryka Wiercieńskiego ${ }^{7}$. Jego pierwsze badania koncentrowały się wokół procesów ludnościowych w parafii Wąwolnica. Wyniki dociekań były na tyle interesujące, że postanowił on rozszerzyć kwerendę o pozostałe parafie Lubelszczyzny. Wykorzystanie ksiąg metrykalnych do badań nad zaludnieniem i ruchem naturalnym dawnego województwa lubelskiego, wiązało się z potrzebą ich inwentaryzacji. W sumie objęła ona ponad 130 parafii położonych na terenie XIX-wiecznej guberni lubelskiej, co odpowiadało granicom historycznej ziemi lubelskiej oraz znacznej części ziemi chełmskiej. Całe przedsięwzięcie nie byłoby możliwe bez życzliwej pomocy ze strony władz kościelnych, o czym wspominał inicjator badań ${ }^{8}$. Szczególnie cennym okazało się zaangażowanie biskupa lubelskiego Franciszka Jaczewskiego. Wydał on polecenie, zgodnie z którym proboszczowie poszczególnych parafii mieli sporządzić wyciągi liczbowe chrztów, ślubów i zgonów od czasów najdawniejszych, aż po 1900 rok, a następnie przesłać je do konsystorza. Efekt tych prac stanowi zestawienie ruchu naturalnego sięgające w niektórych parafiach końca XVI w. ${ }^{9}$ H. Wierciński ograniczył się do publikacji statystyki ludności tylko 75 parafii, od początku XVII w. do 1900 r., w przekrojach 10-letnich ${ }^{10}$.

Akcję inwentaryzacji ksiąg i przeliczania liczb ruchu naturalnego prowadzoną przez H. Wiercieńskiego można uznać za unikatową w skali całego kraju. Wśród ośrodków parafialnych znalazły się również te, będące przedmiotem naszej kwerendy. Dzięki temu mamy możliwość porównania ówczesnych zasobów ze stanem dzisiejszym. Choć efektem akcji jest statystyka liczb ruchu naturalnego, brak zaś szczegółowego katalogu ksiąg, to porównanie dat rocznych pozwala określić ewentualne ubytki w materiale źródłowym. Próby częściowej weryfikacji zawartości ksiąg dokonali już wcześniej Janina Gawrysiakowa i Zygmunt Sułowski. J. Gawrysiakowa ujawniła, że w niektórych parafiach zadanie wykonano sumiennie, w innych zaś zdarzają się większe lub mniejsze niedokładności. Wśród uchybień stwierdzono błędy o charakterze systematycznym. W księgach z okresu trydenckiego nie zawsze poprawnie odczytano liczbę odnotowanych faktów. $\mathrm{W}$ metrykach $\mathrm{z}$ okresu austriackiego zaniżano czasem liczbę poszczególnych elementów ruchu naturalnego, odnotowując tylko dane z miejscowości będącej

Z. Sułowski, Ewidencja ruchu naturalnego ludności oparta na dawnych metrykach parafialnych, „Przeszłość Demograficzna Polski”, 4(1971), s. 5-6. Po zakończeniu II wojny światowej F. Bujak wznowił prace inwentaryzacyjne, objęły one jednak ograniczony obszar. Więcej na ten temat zob.: Hoszowski, Sułowski, Ewidencja ruchu, s. 6.

${ }^{7}$ Por. Z. Sułowski, Ruch naturalny ludności ziemi lubelskiej w latach 1582-1900, „Folia Societatis Scientarium Lublinensis", 18 (1976) Hum. 1, s. 3.

${ }^{8} \mathrm{H}$. Wiercieński, Próbki szperań po archiwach. Z ruchu ludności i zaludnienia na terytorium dawnego województwa lubelskiego w ciagu 3-ch ostatnich stuleci, „Rocznik Polskiego Towarzystwa Krajoznawczego", 4 (1910) s. 316.

${ }^{9}$ Archiwum Archidiecezji Lubelskiej (dalej: AAL), syg. Rep. 60, VI, nr 1. Akta Konsystorza Generalnego Diecezji Lubelskiej. Wykaz statystyczny o ruchu ludności w parafiach dzisiejszych guberni lubelskiej od najdawniejszych czasów do $1901 \mathrm{r}$.

${ }^{10}$ Więcej na ten temat zob. Wiercieński, Próbki szperań. 
siedzibą parafii, opuszczano natomiast zapisy z pozostałych wsi wchodzących w skład parafii. Z kolei dla okresu 1810-1825 zdarzało się błędne dodawanie ludności żydowskiej do ogólnej liczby katolików. W przypadku ślubów zawyżanie ich liczby poprzez doliczanie (wpisywanych do ksiąg małżeństw), wcześniejszych zapowiedzi. Kontrola wykazała także, co najistotniejsze, że w akcji z 1901 r. pominięto niektóre księgi. Jako największe uchybienie w tym zakresie, Z. Sułowski wskazał księgi chrztów i ślubów Lublina z lat $1582-1755^{11}$.

Poniższy wykaz parafii zawiera porównanie najstarszych zapisów uwzględnionych w zestawieniu H. Wiercieńskiego ze stanem obecnym (XII 2015). Pozwala ono stwierdzić ubytki w zasobie, ale pokazuje też, które księgi pominięto w czasie akcji w $1901 \mathrm{r}$.

Tabela 1. Zestawienie najstarszych dat zapisów ruchu naturalnego w księgach metrykalnych przechowywanych $w$ archiwach parafialnych $\mathrm{z}$ wykazem statystycznym $\mathbf{H}$. Wiercieńskiego.

\begin{tabular}{|c|c|c|c|c|c|c|}
\hline \multirow{2}{*}{ Parafia } & \multicolumn{2}{|c|}{ Chrzty } & \multicolumn{2}{c|}{ Śluby } & \multicolumn{2}{c|}{ Zgony } \\
\cline { 2 - 7 } & AP & W & AP & W & AP & W \\
\hline $\mathbf{1}$ & $\mathbf{2}$ & $\mathbf{3}$ & $\mathbf{4}$ & $\mathbf{5}$ & $\mathbf{6}$ & $\mathbf{7}$ \\
\hline Abramowice & 1797 & 1648 & 1797 & 1658 & 1797 & 1712 \\
\hline Baranów & 1810 & 1811 & 1813 & 1811 & 1810 & 1811 \\
\hline Bełżyce & 1605 & 1605 & 1605 & 1606 & 1722 & 1722 \\
\hline Biskupice & 1641 & 1641 & 1690 & 1641 & 1711 & 1711 \\
\hline Bochotnica & 1726 & 1726 & 1728 & 1728 & 1726 & 1726 \\
\hline Bychawa & 1617 & 1617 & 1711 & 1711 & 1771 & 1771 \\
\hline Bychawka & 1787 & 1787 & 1787 & 1787 & 1787 & 1787 \\
\hline Bystrzyca & 1693 & 1693 & 1662 & 1693 & 1770 & 1770 \\
\hline Chodel & 1590 & 1594 & 1721 & 1594 & 1771 & 1594 \\
\hline Czemierniki & 1595 & 1627 & 1615 & 1717 & 1739 & 1740 \\
\hline Czerniejów & 1673 & 1673 & 1668 & 1668 & 1825 & 1736 \\
\hline Częstoborowice & brak & 1702 & brak & 1702 & brak & 1702 \\
\hline Dys & 1647 & 1647 & 1693 & 1699 & 1721 & 1722 \\
\hline Fajsławice & 1757 & 1757 & 1797 & 1758 & 1757 & 1757 \\
\hline Firlej & 1685 & 1687 & 1760 & 1716 & 1719 & 1719 \\
\hline Garbów & brak & 1705 & brak & 1639 & brak & 1726 \\
\hline Gołąb & 1787 & 1614 & 1797 & 1596 & 1776 & 1717 \\
\hline Kamionka & 1710 & 1703 & 1610 & 1610 & 1715 & 1715 \\
\hline Karczmiska & 1710 & 1710 & 1780 & 1783 & 1780 & 1727 \\
\hline Kazimierz Dolny & 1617 & 1614 & 1586 & 1596 & 1687 & 1717 \\
\hline
\end{tabular}

${ }^{11}$ Sułowski, Ruch naturalny, s. 7-8. Niestety poza tymi ogólnymi stwierdzeniami nie opublikowano odpowiednich zestawień. 
PIOTR RACHWAŁ

\begin{tabular}{|c|c|c|c|c|c|c|}
\hline 1 & 2 & 3 & 4 & 5 & 6 & 7 \\
\hline Kiełczewice & 1679 & 1594 & 1797 & 1594 & 1797 & 1594 \\
\hline Kijany & 1725 & 1608 & 1732 & 1601 & 1773 & 1736 \\
\hline Klementowice & 1751 & 1811 & 1797 & 1811 & 1720 & 1811 \\
\hline Kluczkowice & 1786 & 1787 & 1787 & 1787 & 1786 & 1787 \\
\hline Konopnica & 1719 & 1719 & 1730 & 1719 & 1759 & 1759 \\
\hline Końskowola & 1668 & 1668 & 1644 & 1700 & 1718 & 1718 \\
\hline Krasienin & 1604 & 1603 & 1727 & 1603 & 1797 & 1603 \\
\hline Krężnica Jara & 1797 & 1797 & 1797 & 1797 & 1797 & 1797 \\
\hline Krzczonów & 1656 & 1606 & 1618 & 1632 & 1684 & 1694 \\
\hline Kurów & 1628 & 1628 & 1690 & 1690 & 1689 & 1782 \\
\hline Lubartów & 1700 & 1682 & 1663 & 1673 & 1720 & 1721 \\
\hline $\begin{array}{l}\text { Lublin pw. św. Jana } \\
\text { Chrzciciela i św. } \\
\text { Jana Ewangelisty } \\
\text { (archikatedra) }\end{array}$ & 1612 & 1756 & 1595 & 1756 & 1771 & 1756 \\
\hline Lublin św. Mikołaj & 1669 & 1669 & 1669 & 1669 & 1722 & 1722 \\
\hline Łańcuchów & 1786 & 1810 & 1743 & 1810 & 1734 & 1810 \\
\hline Łęczna & 1598 & 1702 & 1627 & 1797 & 1737 & 1797 \\
\hline Łuszczów & 1864 & 1811 & 1864 & 1811 & 1864 & 1811 \\
\hline Markuszów & 1722 & 1722 & 1722 & 1722 & 1722 & 1722 \\
\hline Matczyn & 1687 & 1730 & 1763 & 1763 & 1755 & 1753 \\
\hline Mełgiew & 1687 & 1744 & 1664 & 1797 & 1725 & 1797 \\
\hline Michów & 1765 & 1659 & 1711 & 1705 & 1764 & 1739 \\
\hline Milejów & 1859 & 1859 & 1859 & 1859 & 1859 & 1859 \\
\hline Niedrzwica & 1797 & 1676 & 1797 & 1711 & 1797 & 1719 \\
\hline Opole Lubelskie & 1661 & 1661 & 1635 & 1601 & 1771 & 1717 \\
\hline Piaski & 1673 & 1674 & 1792 & 1674 & 1739 & 1739 \\
\hline Piotrawin & 1599 & 1599 & 1716 & 1596 & 1784 & 1738 \\
\hline Puchaczów & 1797 & 1756 & 1756 & 1756 & 1756 & 1756 \\
\hline Ratoszyn & 1747 & 1747 & 1748 & 1748 & 1748 & 1748 \\
\hline Rudno & 1656 & 1630 & 1791 & 1660 & 1793 & 1760 \\
\hline Serniki & 1697 & 1697 & 1714 & 1697 & 1721 & 1721 \\
\hline Targowisko & 1657 & 1657 & 1656 & 1657 & 1787 & 1737 \\
\hline Wąwolnica & 1635 & 1635 & 1635 & 1638 & 1719 & 1719 \\
\hline Wilkołaz & 1753 & 1753 & 1668 & 1755 & 1757 & 1797 \\
\hline Wilków & 1742 & 1729 & 1741 & 1741 & 1797 & 1729 \\
\hline Włostowice & 1639 & 1640 & 1639 & 1639 & 1721 & 1721 \\
\hline
\end{tabular}




\begin{tabular}{|c|c|c|c|c|c|c|}
\hline $\mathbf{1}$ & $\mathbf{2}$ & $\mathbf{3}$ & $\mathbf{4}$ & $\mathbf{5}$ & $\mathbf{6}$ & $\mathbf{7}$ \\
\hline Wojciechów & 1689 & 1689 & 1689 & 1689 & 1724 & 1725 \\
\hline Wysokie & 1693 & 1639 & 1726 & 1726 & 1737 & 1737 \\
\hline Zemborzyce & 1770 & 1797 & 1771 & 1797 & 1810 & 1797 \\
\hline Żyrzyn & 1741 & 1672 & 1755 & 1715 & 1728 & 1722 \\
\hline
\end{tabular}

AP - archiwum parafialne, W - wykaz statystyczny H. Wiercieńskiego. Źródło: AAL, Rep. 60, VI, nr 1. Akta Konsystorza Generalnego Diecezji Lubelskiej. Wykaz statystyczny o ruchu ludności w parafiach dzisiejszych guberni lubelskiej od najdawniejszych czasów do 1901 roku; Księgi metrykalne przechowywane w wymienionych archiwach parafialnych.

W wykazie zabrakło dwóch parafii tj. Ostrowa Lubelskiego i Parczewa. W 1900 r. należały one do dekanatu włodawskiego, którego nie objęła inicjatywa H. Wiercieńskiego. W przypadku metryk chrztów z 14 parafii zapisy mają starszą proweniencję niż obecnie przechowywane w archiwach. Największą różnicę odnotowano dla parafii: Abramowic, Gołębia, Kijan, Michowa i Niedrzwicy. Statystyka z 1901 r. pokazuje, że w parafiach tych znajdowały się księgi metrykalne starsze o ponad 100 lat od tych zachowanych współcześnie. W przypadku parafii Niedrzwica brakujące księgi przechowywane są w Archiwum Państwowym w Lublinie ${ }^{12}$, co do pozostałych należy przypuszczać, że najprawdopodobniej uległy one zniszczeniu i zostały tym samym bezpowrotnie stracone. Być może część $\mathrm{z}$ nich znajduje się $\mathrm{w}$ rękach prywatnych. Porównanie metryk ślubów wskazuje na jeszcze większe ubytki zasobu jaki dokonał się w ciągu ostatnich 100 lat. W parafii Kiełczewice oraz Gołąb odnotowano księgi ślubów starsze o ponad 200 lat, od przechowywanych obecnie. Dla ośmiu kolejnych ośrodków różnica wynosi ponad 100 lat. Z kolei porównanie rejestracji metrykalnej zgonów z początku XX w. z trzech parafii: Chodla, Kiełczewic i Krasienina ze stanem obecnym ujawniło braki sięgające 200 lat.

Zestawienie stanu obecnego archiwaliów ze statystyką H. Wiercieńskiego pokazuje także, że w 1901 r. nie uwzględniono części ksiąg współcześnie przechowywanych $\mathrm{w}$ archiwach parafialnych. Znaczne różnice pomiędzy najstarszymi zapisami metrykalnymi występują $\mathrm{w}$ zasobie ksiąg parafii Czemierniki, parafii pw. św. Jana Chrzciciela i św. Jana Ewangelisty w Lublinie, Łęcznej i Mełgwi.

Szczegółowe zestawienie liczb ruchu naturalnego wskazuje, że częstym uchybieniem osób które sporządzały statystyki w 1901 r. było rozpoczynanie zestawienia od pełnego roku i zaniechanie wpisów dla poprzedniego, niepełnego. Tak było np. w przypadku początku rejestracji ślubów parafii: Bełżyce, Dys, chrztów w parafiach: Włostowice, Piaski, czy też zgonów w parafiach: Czemierniki, Dys, Lubartów, Wojciechów. Innym uchybieniem były opuszczenia powstałe w czasie katalogowania i przeliczania ksiąg współoprawnych, tj. zawierających więcej niż jedną serię faktów ruchu naturalnego. Sytuację taką stwierdzono m.in. w parafii Chodel, Dys i Lubartów.

${ }^{12}$ Archiwum Państwowe w Lublinie (dalej: APL), syg. 106/56, Akta parafii rzymskokatolickiej w Niedrzwicy 1675-1802. 
Pomimo wskazanych wyżej niedociągnięć, rezultaty akcji przeprowadzonej $z$ inicjatywy $\mathrm{H}$. Wiercińskiego są nie do przecenienia. Zawartość statystyk jest nie tylko cennym źródłem dla badaczy zajmujących się procesami ludnościowymi zachodzącymi w przeszłości, ale co istotne z perspektywy prowadzonego dyskursu, pozwala ustalić braki w materiale źródłowym jakie powstały na przestrzeni ostatnich 100 lat. Szczególnie dotkliwą stratą jest brak całego zespołu ksiąg metrykalnych parafii Garbów. Został on zniszczony w czasie pożaru w $1915 \mathrm{r}^{13}$ Wielką stratą jest także zaginięcie całego zespołu metryk, sprzed 1900 r., z parafii Częstoborowice. W tym przypadku, nie wiadomo w jakich okolicznościach źródła te zaginęły. W świetle wykazów H. Wiercieńskiego, w parafii utrzymywano księgi metrykalne z początku XVIII w. Co istotne, jeszcze na początku lat 70. XX w. przechowywano je $\mathrm{w}$ archiwum parafialnym ${ }^{14}$.

\section{Po drugiej wojnie światowej}

W latach 50. ubiegłego wieku, środowisko historyków wielokrotnie wysuwało postulaty uaktualnienia wiedzy na temat zasobów ksiąg metrykalnych ${ }^{15}$. $\mathrm{Z}$ podobną inicjatywą odnoszącą się do ziemi lubelskiej wystąpił Z. Sułowski ${ }^{16}$. W 1954 r. zajął się on materiałami zgromadzonymi przez H. Wiercieńskiego ${ }^{17}$. Zainteresowanie to wynikało z faktu, że na seminarium magisterskim dla historyków prowadzonym w Katolickim Uniwersytecie Lubelskim, wielu jego studentów wyraziło wolę wykorzystania metryk w badaniach regionalnych, w tym szczególnie z zakresu demografii historycznej. W porozumieniu z ówczesnymi władzami diecezji lubelskiej, przygotowano i rozesłano ankietę do proboszczów z prośbą o przygotowanie wykazów zachowanych ksiąg metrykalnych. $\mathrm{Na}$ an-

${ }^{13}$ Całe archiwum parafialne uległo zniszczeniu wskutek spalenia kościoła parafialnego przez Rosjan 30 lipca 1915 r. W czasie pierwszej wojny światowej przechowywano je w ukryciu w grobowcach hrabiów Jezierskich, właścicieli Garbowa, które znajdowały się w podziemiach kościoła. Podczas pożaru wszystkie dokumenty historyczne spłonęły. Źródło: http://naszgarbow.pl/garbowskie-ksiegi-metrykalne-stan-zachowania-i-dostepnosc-online/ (dostęp: 10.01.2015).

${ }^{14} \mathrm{~W}$ czasie akcji mikrofilmowania ksiąg metrykalnych z obszaru Lubelszczyzny prowadzonej w Archiwum Państwowym w Lublinie w 1972-1973 r. zostały one przywiezione do Lublina. Potwierdza to wykaz ksiąg dostarczonych wówczas do archiwum, sporządzony przez J. Gawrysiakową. Za jego udostępnienie składam dr Janinie Gawrysiakowej gorące podziękowania.

${ }^{15}$ Hoszowski, Dynamika rozwoju, s. 154-161; W. Kula, Stan i potrzeby badań nad demografia historyczna dawnej Polski (do początków XIX w.), RDSG, 13 (1951) s . 23-110; W. Kula, Problemy i metody historii gospodarczej, Warszawa 1963, s. 407 i nn.; I. Gieysztorowa, Badania demograficzne na podstawie metryk parafialnych, Kw.HKM, 10 (1962) s. 103.

${ }^{16} \mathrm{Z}$. Sułowski, $O$ wtaściwa metodę wykorzystywania metryk kościelnych dla badań demograficznych, Kw.HKM, 10 (1962) s. 81-100.

${ }^{17}$ W dniu 29 listopada 1962 r. na spotkaniu Towarzystwa Naukowego KUL Z. Sułowski przedstawił projekt publikacji, obejmującej krytyczne wydanie tablic ruchu naturalnego powstałych z inicjatywy H. Wiercieńskiego. Publikacja miała liczyć ok. 90 tablic, poprzedzonych opisem sieci parafialnej, oceną kompletności rejestracji, oceną pracy osób przeliczających dane w $1901 \mathrm{r}$. oraz obliczenie i prezentację podstawowych współczynników demograficznych. Zob. „Sprawozdania z czynności wydawniczej i posiedzeń naukowych oraz Kronika Towarzystwa Naukowego Katolickiego Uniwersytetu Lubelskiego", 13 (1962) s. 34-36. Niestety, zapowiedzi te nie zostały spełnione. 
kietę odpowiedziały tylko niektóre parafie. Jej wyniki ujawniły, że część zasobu z 1901 r. przestał istnieć, sama zaś akcja została źle oceniona ${ }^{18}$.

Pewne ustalenia w tym zakresie poczynił natomiast ks. Franciszek Stopniak. W artykule poświęconym archiwom parafialnym dekanatu lubelskiego znalazły się m.in. informacje o aktualnym zasobie ksiąg metrykalnych. Badania objęły parafie: Abramowice, Czerniejów, Dys, Konopnica, Zemborzyce, Lublin (pw. św. Agnieszki), Lublin (pw. św. Jana Chrzciciela), Lublin (pw. św. Mikołaja), Lublin (pw. św. Pawła) ${ }^{19}$. Księgi metrykalne opisano podając daty skrajne, dla trzech rodzajów zapisów. Choć wykaz ten jest niepełny, to docenić należy wkład pracy włożony przez autora, wynikający z osobistej eksploracji archiwów.

Okazja do weryfikacji danych nadesłanych w $1901 \mathrm{r}$. na prośbę bpa F. Jaczewskiego oraz pozyskanych dzięki wspomnianej ankiecie z 1954 r., nadarzyła się w latach 70. XX w. Już wcześniej, tj. w latach 60. Naczelna Dyrekcja Archiwów Państwowych (NDAP) podpisała umowę z Towarzystwem Genealogicznym stanu Utah z siedzibą w Salt Lake City ${ }^{20}$. Towarzystwo to działa pod auspicjami Kościoła Jezusa Chrystusa Świętych w Dniach Ostatnich, zwanego potocznie kościołem mormonów. W oparciu o przesłanki religijne dążą oni do zgromadzenia jak największej liczby metryk, co w praktyce sprowadza się przed wszystkim do sporządzania mikrofilmów z ksiąg metrykalnych z całego świata. Stosowne porozumienie zostało zawarte z NDAP oraz z niektórymi diecezjalnymi władzami kościelnymi ${ }^{21}$. Zgodę wydała także diecezja lubelska, mimo to niektóre parafie odmówiły udostępnienia swoich zasobów. W sumie do Lublina, w celu sporządzenia mikrofilmów, przywieziono w latach 1968-1973 księgi z 64 parafii Lubelszczyzny. Wśród nich znalazły się metryki 31 parafii objętych naszymi badaniami: Bełżyce, Bochotnica, Bychawa, Bychawka, Bystrzyca, Chodel, Czemierniki, Częstoborowice, Dys, Firlej, Karczmiska, Kamionka, Kijany, Krasienin, Lubartów, Lublin (pw. św. Jana Chrzciciela i św. Jana Ewangelisty), Lublin (pw. św. Mikołaja), Łańcuchów, Łęczna, Matczyn, Michów, Niedrzwica, Piaski, Puchaczów, Rudno, Serniki, Targowisko, Wilkołaz, Krężnica Jara, Wysokie, Żyrzyn ${ }^{22}$.

Korzystając $\mathrm{z}$ faktu zgromadzenia w archiwum państwowym rozproszonych do tej pory zasobów, Z. Sułowski oraz J. Gawrysiakowa przejrzeli księgi z kilkudziesięciu parafii. Ta żmudna praca zaowocowała ustaleniami dotyczącymi

${ }^{18}$ Sułowski, Ruch naturalny, s. 5.

${ }^{19}$ F. Stopniak, Archiwa parafialne dekanatu lubelskiego, „Archiwa Biblioteki i Muzea Kościelne" (dalej: ABMK), 9 (1964) s. 5-19.

${ }^{20}$ A. Biernat, Księgi metrykalne w archiwach państwowych, ABMK, 75 (2001) s. 73.

${ }^{21} \mathrm{Na}$ zmikrofilmowanie metryk wyraziły zgodę kurie w: Pelpinie, Drohiczynie, Gnieźnie, Katowicach, Krakowie, Lubaczowie, Lublinie, łodzi, Łomży, Olsztynie, Opolu, Poznaniu, Sandomierzu, Tarnowie. Tamże, s. 74.

${ }^{22}$ Pozostałe parafie , które udostępniły swoje zasoby to: Biłgoraj, Blinów, Boiska, Borów, Boża Wola, Chełm, Chłaniów, Dorohusk, Gościeradów, Gródek, Hrubieszów, Huta Krzeszowska, Janów Lubelski, Krasnystaw, Kraśnik, Łukowa, Olchowiec, Pławanice, Płonka, Potok Górny, Potok Wielki, Rachanie, Radzięcin, Rzeczyca Ziemiańska, Świeciechów, Świerże, Tarnogród, Tarnogóra, Turobin, Urzędów, Kumów, Wożuczyn, Żółkiewka. W ramach prowadzonej akcji zmikrofilmowano także XIX-wieczne akta cywilne przechowywane w Archiwum Państwowy w Lublinie. 
błędów natury systematycznej jak i przypadkowej, pojawiającymi się w liczbach ruchu naturalnego zebranych w czasie akcji $\mathrm{H}$. Wiercieńskiego. Wyniki prowadzonej kwerendy J. Gawrysiakowa opublikowała na łamach „Przeszłości Demograficznej Polski”. Zestawienie zachowanych ksiąg metrykalnych obejmuje 42 parafie ziemi lubelskiej ${ }^{23}$. Przyjęta metodologia opisu zakładała prezentację ciągów zapisów, a nie poszczególnych ksiąg. Ujęcie takie, słuszne z perspektywy przydatności np. dla badań demograficznych, utrudnia porównywalność opisywanego materiału źródłowego z aktualnym stanem zasobów. Pozyskany wówczas materiału posłużył też J. Gawrysiakowej do oceny wartości źródłowej rejestracji ruchu naturalnego w Lubelskiem w XIX wieku' ${ }^{24}$.

Po zakończeniu akcji mikrofilmowania, oryginały ksiąg zostały odesłane archiwom parafialnym. Negatywy mikrofilmów trafiły do mormonów, natomiast kopie pozytywowe otrzymały lubelskie: Archiwum Diecezjalne oraz Archiwum Państwowe. Obecnie część mikrofilmów znajduje się w złym stanie, co uniemożliwia korzystanie $\mathrm{z}$ nich. W latach 90 . XX w. oraz początku XXI w., w porozumieniu z kurią lubelską, mormoni przeprowadzili kolejną akcję mikrofilmowania, jednak już na wiele mniejszą skalę niż to miało miejsce wcześniej. Od pewnego czasu prowadzą też digitalizację zgromadzonych przez siebie materiałów, a część $\mathrm{z}$ nich (XIX w.) udostępniono w Internecie ${ }^{25}$.

\section{Struktura notki katalogowej}

Jednostki archiwalne pozbawione są oryginalnych sygnatur, stąd każdej nadano numerację według stałego schematu. Pierwsza liczba w sygnaturze oznacza numer parafii, kolejne, oddzielone podkreślnikiem, rodzaj serii (chrztów - 1, ślubów -2 , zgonów -3) i numer kolejnej księgi w danej serii ${ }^{26}$. Opis każdej z ksiąg składa się z kilku elementów oddzielonych średnikiem, tj. tytułu jednostki archiwalnej umieszczonego na okładce (w sytuacji gdy księga nie posiadała tytułu, nadano go w nawiasach kwadratowych), dat skrajnych zapisów metrykalnych oznaczonych miesiącem i rokiem (daty w tytule księgi nie zawsze są zgodne ze stanem faktycznym), rodzaju formularza (f. t. - formularz trydencki, f. a. - formularz austriacki, f. p. - formularz polski), języka w jakim sporządzono wpisy (łac. - łacina, pol. - polski, ros. - rosyjski), liczby stron - jeśli numeracja była prowadzona, w przeciwnym wypadku na oznaczenie numeracji użyto skrótu „bns”. Przykładowy opis

${ }^{23}$ J. Gawrysiakowa, Zasoby archiwów parafialnych, ziemia lubelska, parafie rzymskokatolickie. Stan na 1 II 1980 r., PDP, 13 (1981) s. 119-124. Wykaz zachowanych ksiąg metrykalnych w dekanacie Kazimierz nad Wisłą na 1782 r. sporządził także B. Kumor, Dzieje diecezji krakowskiej do roku 1795, Kraków 2002, s. 678.

${ }^{24}$ Gawrysiakowa, Grupy wyznaniowe. Pełny wykaz wykorzystanych ksiąg znajduje się na str.143-166.

${ }^{25}$ Także Archiwum Państwowe w Lublinie od kilku lat sporządza kopie cyfrowe akt stanu cywilnego. Można je przeglądać pod adresem: www.szukajwarchiwach.pl (dostęp: 30.11.2017).

${ }^{26}$ Według tego samego schematu, nadano sygnatury skanom cyfrowym wykonanym $\mathrm{w}$ trakcie realizacji projektu. W przypadku kopii cyfrowych ksiąg, numerację uzupełniono o czwartą liczbę, oznaczającą kolejność kart w obrębie księgi. 
najstarszej księgi chrztów z parafii Abramowice - „3_1_1; Księga urodzeń od roku 1797; I 1797-XII 1825; f. a.; łac.; 192 + bns.”, zawiera następujące elementy: „3_1_1" - sygnatura księgi

„Księga urodzeń od roku 1797” - tytuł umieszczony na okładce;

„I 1797-XII 1825" - faktyczne daty skrajne zapisów;

„f. a." - księga prowadzona według formularza austriackiego;

„łac.” - zapisy sporządzono w języku łacińskim;

„192 + bns.” - księga składa się ze 192 numerowanych stron i dodatkowo kart nienumerowanych.

W przypadku opisu ksiąg prowadzonych według formularza trydenckiego i w wyjątkowych przypadkach dla metryk sporządzanych według innych formularzy, dołączono uwagi. Zawierają one informacje o formacie księgi, materiale oprawy, zniszczeniach, ubytkach itp., a także adnotacje o kontroli prowadzonej w czasie wizytacji dziekańskiej.

$* * * *$

\section{ANEKS}

\section{ABRAMOWICE}

\section{Chrzty}

3_1_1; Księga urodzeń od roku 1797; I 1797-XII 1825; f. a.; łac.; $192+$ bns.

3_1_2; Księga akt cywilnych urodzenia, uznania, przysposobienia, zapowiedzi, małżeństw i zejścia w parafii abramowickiej 1811 roku; I 1811-XII 1811; f. p.; pol.; 182.

3_1_3; Urodzonych 1817; I 1817-XII 1817; f. p.; pol.; 90.

3_1_4; Urodzonych 1818; I 1818-XII 1818; f. p.; pol.; 90.

3_1_5; Akta urodzonych od roku 1826 do roku 1834; I 1826-IX 1834; f. p.; pol.; 380 .

3_1_6; Akta urodzonych poczynając od numeru 69. roku 1834 do numeru 51. roku 1849; IX 1834-VI 1849; f. p.; pol.; 478.

3_1_7; Akta urodzonych poczynające od numeru 52. roku 1849 po numer 15. roku 1862; VI 1849-II 1862; f. p.; pol.; 472.

3_1_8; Akta urodzonych poczynając od numeru 16. roku 1862 do roku 1868; II 1862-XII 1868; f. p.; pol./ros. VI 1868 r.; 352.

3_1_9; Akta urodzonych roku 1869-1878; I 1869-XII 1878; f. p.; ros.; 472.

3_1_10; Akta urodzonych od roku 1879 do numeru 135 roku 1890; I 1879-XII 1890; f. p.; ros.; 554.

3_1_11; Akta urodzonych poczynając od numeru 135. roku 1890 do końca roku 1896; IX 1890-XII 1896; f. p.; ros.; 378.

3_1_12; Akta urodzonych od roku 1897 do numeru 81. roku 1903; I 1897-V 1903; f. p.; ros.; 469 . 


\section{Śluby}

3_2_1; [Liber copulatorum ab anno 1797]; I 1797-XI 1825; f. a.; łac.; 200.

3_2_2; Akta stanu cywilnego gminy abramowickiej tyczące się obchodu małżeństwa i zapowiedzi na rok 1814. Do archiwum gminy Abramowice; I 1814-XII 1814; f. p.; pol.; 66.

3_2_3; Akta stanu cywilnego gminy abramowickiej tyczące się obchodu małżeństwa i zapowiedzi w roku 1815. Do archiwum gminy Abramowice; I 1815-XII 1815; f. p.; pol.; $37+$ bns.

3_2_4; Akta stanu cywilnego gminy abramowickiej tyczące się obchodu małżeństwa i zapowiedzi w roku 1816. Do archiwum gminy abramowickiej; I 1816XII 1816; f. p.; pol.; $57+$ bns.

3_2_5; Akta stanu cywilnego gminy abramowickiej tyczące się obchodu małżeństwa i zapowiedzi w roku 1817. Do archiwum gminy abramowickiej; I 1817XII 1817; f. p.; pol.; 86.

3_2_6; Liber metrices copulatorum pro legione primo levisarmturac militum exrcitus Polona comparatus anno domini 1817; VII 1817-I 1825; f. p.; łac.; bns.

3_2_7; Księga obchodu małżeństwa, akta stanu cywilnego gminy abramowickiej na rok 1819. Do kancelarii sądu pokoju; I 1819-XII 1819; f. p.; pol.; 88.

3_2_8; Księga obchodu małżeństwa akta stanu cywilnego gminy abramowickiej na rok 1820. Do archiwum gminy abramowickiej; I 1820-XII 1820; f. p.; pol.; 92.

3_2_9; Księga obchodu małżeństwa akta stanu cywilnego gminy abramowickiej na rok 1825. Do kancelarii sądu pokoju; I 1825-XII 1825; f. p.; pol.; 90.

3_2_10; Akta zaślubionych od roku 1826 do numeru 9. roku 1856; I 1826-VI 1856; f. a. ; łac.; 376.

3_2_11; Akta zaślubionych poczynając od numeru... w roku 1856 do numeru 26. roku 1881; V 1856-IX 1881; f. p.; pol./ros. VII 1868 r.; 375.

3_2_12; Akta zaślubionych poczynając od numeru 27. roku 1881 do numeru 23. roku 1906; IX 1881-VI 1906; f. p.; ros.; 560.

\section{Zgony}

3_3_1; Księga metryk umarłych za rządu austriackiego utrzymywanych od roku 1797 zaczynające się w parafii abramowickiej; I 1797-XII 1825; f. a.; łac.; $156+$ bns.

33 2; Księga gminy abramowickiej do zapisywania aktów śmierci 1813 roku. Do archiwum gminy abramowickiej; I 1813-XII 1813; f. p.; pol.; 78.

3_3_3; Księga zejścia akt cywilnych gminy abramowickiej na rok 1814.Do archiwum gminy; I 1814-XII 1814; f. p.; pol.; 200.

3_3_4; Księga zejścia akt cywilnych gminy abramowickiej na rok 1815. Do archiwum gminy Abramowice; I 1815-XII 1815; f. p.; pol.; 78.

3_3_5; Księga zejścia akt cywilnych gminy abramowickiej na rok 1816. Do archiwum gminy abramowickiej; I 1816-XII 1816; f. p.; pol.; 74.

3_3_6; Księga zejścia akt cywilnych gminy abramowickiej na rok 1817. Do archiwum gminy abramowickiej; I 1817-XII 1817; f. p.; pol.; 91. 
3_3_7; Księga zejścia akt cywilnych gminy abramowickiej na rok 1819. Do kancelarii sądu pokoju powiatu lubelskiego; I 1819-XII 1819; f. p.; pol.; 88.

3_3_8; Księga zejścia akt cywilnych gminy abramowickiej na rok 1820. Do archiwum gminy abramowickiej; I 1820-XII 1820; f. p.; pol.; 92.

3_3_9; Księga zejścia akt cywilnych gminy abramowickiej na rok 1821. Do kancelarii sądu pokoju; I 1821-XII 1821; f. p.; pol.; 92.

3_3_10; Księga zejścia akt cywilnych gminy abramowickiej na rok 1822. Do archiwum gminy abramowickiej; I 1822-XII 1822; f. p.; pol.; 92.

3_3_11; Księga zejścia akt cywilnych gminy abramowickiej na rok 1823. Do archiwum gminy abramowickiej; I 1823-XII 1823; f. p.; pol.; 92.

3_3_12; Księga zejścia akt cywilnych gminy abramowickiej na rok 1824. Do kancelarii sądu pokoju; I 1824-XII 1824; f. p.; pol.; 88.

3_3_13; Księga zejścia akt cywilnych gminy abramowickiej na rok 1825 . Do archiwum gminy abramowickiej; I 1825-XII 1825; f. p.; pol.; 94.

3_3_14; Akta zmarłych poczynając od numeru 1. roku 1876 do numeru 52. roku 1896; I 1876-V 1896; f. p.; ros.; 468.

3_3_15; Akta zmarłych poczynając od numeru 53. roku 1896 do numeru 112. roku 1907; V 1896-XI 1907; f. p.; ros.; 364.

\section{BARANÓW}

\section{Chrzty}

54_1_1; [Księga urodzeń od 1810 roku]; IX 1810-XII 1825; f. p.; pol.; bns.

54_1_2; [Księga urodzeń, małżeństw i zgonów od 1824 roku]; I 1824-XII 1824; f. p.; pol.; 136 .

54_1_3; [Księga urodzeń, małżeństw i zgonów od 1825 roku]; I 1825-XII 1825; f. p.; pol.; 116 .

54_1_4; [Księga urodzeń od 1826 roku]; I 1826-XII 1836; f. p; pol.; 298.

54_1_5; [Księga urodzeń od 1837 roku]; I 1837-XII 1848; f. p.; pol.; bns.

54_1_6; [Księga urodzeń od 1849 roku]; I 1849-XII 1861; f. p.; pol.; 372.

54_1_7; [Księga urodzeń od 1862 roku]; I 1862-I 1874; f. p./f. t. X 1868 r.; pol./ lac. X 1868 r.; 376.

54_1_8; Akty rodivšihsâ v Baranovskom rimsko-katoličeskom prihode s 1870 goda po 1874 god.; XI 1870-XII 1874; f. p.; ros.; 124.

54_1_9; [Kniga rodivšihsâ s 1875 goda]; I 1875-XI 1886; f. p.; ros.; 376.

54_1_10; Akta urodzonych parafii Barnów z 1886 roku po 1895; I 1886-IX 1895; f. p.; ros.; 652 .

54_1_11; Akta urodzonych parafii Baranów z 1895 roku po 1903 rok; IX 1895-VI 1903; f. p.; ros.; 566.

\section{Śluby}

54_2_1; Akta zaślubionych parafii Baranów z 1813 roku po 1825 roku; I 1813-XI 1825 ; f. p.; pol.; bns.

54_2_2; Księga małżeństwa gminy Baranów na rok 1826 do 1843; I 1826-XI 1843; f. p.; pol.; 210. 
54_2_3; Akta zaślubionych parafii Baranów z 1844 roku po 1860 roku; I 1844-XI 1859; f. p.; pol.; 180 .

54_2_4; Akta zaślubionych parafii baranowskiej od roku 1860; I 1860-XI 1873; f. p.; pol./lac. XI 1868 r.; 282.

54_2_5; Akta zaślubionych parafii Baranów z 1868 roku po 1874 rok; I 1868-XI 1875 ; f. p.; ros.; 92.

54_2_6; Akta zaślubionych parafii Baranów z 1875 roku po 1882 rok; XI 1875-XI 1882; f. p.; ros.; 94.

54_2_7; [Kniga brakosočetavšichsâ s 1883 goda]; I 1883-XII 1898; f. p.; ros.; 282 .

54_2_8; Unikat aktov graždanskago sostoâniâ prihoda Baranov o brakosočetavšihsâ v 1899 godu.; I 1899-I 1909; f. p.; ros.; bns.

\section{Zgony}

54_3_1; Akta zmarłych parafii Baranów 1810 roku po 1823 rok; IX 1810-XII $1 \overline{8} 23$; f. p.; pol.; bns.

54_3_2; [Księga zgonów od 1826 roku]; I 1826-IX 1843; f. p.; pol.; 290.

54_3_3; Akta zmarłych parafii Baranów z 1843 roku po 1859 rok; X 1843-XII 1859; f. p.; pol.; 376 .

54_3_4; Akta zejścia kościoła parafii baranowskiej od roku 1860; I 1860-XII 1873; f. p.; pol./łac. X 1868 r.; 282.

54_3 5; Akta zmarłych parafii Baranów z 1868 roku po 1873 rok; I 1868-VI 1873 ; f. p.; ros.; 91.

54_3_6; [Kniga smerti s 1873 goda]; VI 1873-IX 1876; f. p.; ros.; 46.

54_3_7; Akta zmarłych parafii Baranów z 1876 roku po 1885 rok; IX 1876-XII 1885; f. p.; ros.; 188.

54_3_8; Kniga aktov ob umerših Baranovskogo rimsko-katoličeskago prihoda s $1 \overline{8} 86$ goda po 1904.; I 1886-XII 1904; f. p.; ros.; 328.

\section{BEŁŻYCE}

\section{Chrzty}

17_1_1; Natorum ab anno 1605 ad annum 1622; III 1605-XI 1622; f. t. ; łac.; 244.

Uwagi: Księga formatu dutki, oprawiona w półskórek. Na brzegach pierwszej karty ubytki, które uniemożliwiają odczytanie kilku wpisów. Na str. 119-122 ciemne plamy oraz wyblakły atrament. Na str. 183 i 209 oderwany dół karty. Większość kart ma podklejony (paskiem papieru) wewnętrzny margines. Na ostatniej stronie wpis dziekana lubelskiego z 27 X 1853 r. potwierdzający kontrolę rejestracji.

17 1 2; Natorum 1628-1646; VIII 1628-XII 1645; f. t. ; łac.; 357.

Uwagi: Księga formatu dutki, oprawiona w półskórek. Okładka częściowo uszkodzona, z oberwanymi fragmentami lica. Dolne partie pierwszych 14. kart są poszarpane. W kilku miejscach blok księgi rozkleja się, str. 76 luzem. Część kart ma podklejony (paskiem papieru) wewnętrzny margines. Na ostatniej stronie wpis dziekana lubelskiego z 27 X 1853 r. potwierdzający kontrolę księgi.

17_1_3; Natorum 1646-1664; XII 1645-XI 1664; f. t. ; łac.; 332.

Uwagi: Księga formatu dutki, oprawiona w półskórek. Część kart ma podklejony (paskiem papieru) wewnętrzny margines. Wolumin w kilku miejscach rozkleja się, a str. 301-308 wypadają. Za- 
pisy na stronach $83-90$ obrócone o $180^{\circ}$. Na ostatniej stronie wpis dziekana lubelskiego z $27 \mathrm{X}$ 1853 r. potwierdzający kontrolę księgi.

17 1_4; Natorum od roku 1665 do roku 1678; XI 1665-XII 1678; f. t. ; łac.; 250.

Uwagi: Księga formatu dutki, oprawiona w półskórek. Brakuje połowy strony tytułowej. Część kart ma podklejony wewnętrzny margines, ślady zniszczeń po insektach (niewielkie ubytki). W kilku miejscach blok księgi rozkleja się, a karty częściowo wypadają. Na ostatniej stronie wpis dziekana lubelskiego z 27 X 1853 r. potwierdzający kontrolę księgi.

17 1_5; Natorum ab anno 1679 ad annum 1698; I 1679-II 1698; f. t. ; łac.; 361.

Uwagi: Księga formatu dutki, oprawiona w półskórek. Na stronie tytułowej brak dolnego fragmentu. Od str. 1. do 45. ślady zawilgocenia. Część kart ma podklejony (paskiem papieru) wewnętrzny margines. Na ostatniej stronie wpis dziekana lubelskiego z 27 X 1853 r. potwierdzający kontrolę księgi.

17_1_6; Natorum ab anno 1698 ad annum 1723/4; II 1698-VII 1724; f. t. ; łac.; $3 \overline{4} 0$.

Uwagi: Księga formatu dutki, oprawiona w półskórek. Część kart ma podklejony wewnętrzny margines. Na ostatniej stronie księgi krótkie kalendarium wydarzeń - obejmuje lata 1695-1702. Na końcu księgi wpis dziekana lubelskiego z 27 X 1853 r. potwierdzający kontrolę rejestracji.

17_1_7; [Liber metrices baptisatorum ab anno 1724 ]; VII 1724-X 1762; f. t. ; łac.; 534.

Uwagi: Księga formatu dutki, oprawiona w półskórek. Blok księgi rozkleja się w kilku miejscach, karty dobrze osadzone.

17_1_8; Natorum 1762-1788; X 1762-III 1789; f. t. ; łac.; 350.

Uwagi: Księga formatu dutki, oprawiona w półskórek. Grzbiet okładki odkleił się od bloku, jednak poszczególne składki ściśle przylegają do siebie. Na ostatniej stronie wpis dziekana lubelskiego z 27 X 1853 r. potwierdzający kontrolę księgi.

17_1_9; [Liber metrices baptisatorum ab anno 1789]; III 1789-XII 1819; f. t. ; łac.; 267.

Uwagi: Księga formatu pełnego arkusza, oprawiona w półskórek. Na końcu woluminu znajduje się spis osób, które ofiarowały pieniądze na budowę ołtarza głównego w kościele parafialnym. $\mathrm{Na}$ ostatniej stronie wpis dziekana lubelskiego z 27 X 1853 r. potwierdzający kontrolę księgi.

17 1_10; Liber natorum parochiae Bełżycensis compactus anno domini 1797 do 1808; I 1797-VIII 1810; f. a.; łac.; 174.

17_1_11; Księga akt cywilnych urodzenia, małżeństwa, zejścia parafii bełżyckiej roku 1810; VIII 1810-XII 1810; f. p.; pol.; 184.

17 1_12; Księga aktów stanu cywilnego urodzenia, małżeństwa, zejścia parafii bełżyckiej roku 1811; I 1811-XII 1811; f. p.; pol.; 145.

17 1_13; Księga aktów stanu cywilnego urodzenia, małżeństwa, zejścia parafii bełżyckiej roku 1812; I 1812-XII 1812; f. p.; pol.; 159.

17 1_14; Księga aktów stanu cywilnego urodzenia, małżeństwa, zejścia parafii bełżyckiej roku 1813; I 1813-XII 1813; f. p.; pol.; 219.

17 1_15; Księga aktów stanu cywilnego urodzenia, małżeństwa, zejścia parafii bełżyckiej roku 1814; I 1814-XII 1814; f. p.; pol.; 173.

17 1_16; Księga aktów stanu cywilnego urodzenia, małżeństwa, zejścia parafii bełżyckiej roku 1815; I 1815-XII 1815; f. p.; pol.; 135.

17 1_17; Księga aktów stanu cywilnego urodzenia, małżeństwa, zejścia parafii bełżyckiej roku 1816; I 1816-XII 1816; f. p.; pol.; 63. 
17_1_18; Księga aktów stanu cywilnego urodzenia, małżeństwa, zejścia parafii bełżyckiej roku 1817; I 1817-XII 1817; f. p.; pol.; 113.

17_1_19; Księga aktów stanu cywilnego urodzenia, małżeństwa, zejścia parafii bełżyckiej roku 1818; I 1818-XII 1818; f. p.; pol.; 109.

17_1_20; Księga aktów stanu cywilnego urodzenia,małżeństwa, zejścia parafii bełżyckiej roku 1819; I 1819-XII 1819; f. p.; pol.; 122.

171 21; [Księga urodzeń od roku 1820]; I 1820-XII 1825; f. p.; pol.; 107.

17_1_22; Księga aktów stanu cywilnego urodzenia,małżeństwa, zejścia parafii bełżyckiej roku 1820; I 1820-XII 1820; f. p.; pol.; 133.

17_1_23; Księga aktów stanu cywilnego urodzenia,małżeństwa, zejścia parafii bełżyckiej roku 1821; I 1821-XII 1821; f. p.; pol.; 136.

17_1_24; Akta urodzenia, znania i przysposobienia, zapowiedzi, małżeństw, zejścia czyli śmierci gminy Bełżyce na rok 1822; I 1822-XII 1822; f. p.; pol.; 140.

17_1_25; Akta urodzenia, małżeństw i zejścia gminy Bełżyce na rok 1823; I 1823-XII 1823; f. p.; pol.; 140.

17_1_26; Akta urodzenia, znania i przysposobienia, zapowiedzi, małżeństw, zejścia czyli śmierci gminy Bełżyce na rok 1824; I 1824-XII 1824; f. p.; pol.; 140.

17_1_27; Akta urodzenia, znania i przysposobienia, zapowiedzi, małżeństw, zejścia czyli śmierci gminy Bełżyce na rok 1825; I 1825-XII 1825; f. p.; pol.; 140.

17_1_28; Księga aktów urodzonych bełżyckiej rzymskokatolickiej parafii od $1 \overline{8} 26$ do 1833 roku; I 1826-III 1833; f. p.; pol.; 260.

17_1_29; Księga aktów urodzonych bełżyckiej rzymskokatolickiej parafii od $1 \overline{833}$ do 1839 roku; IV 1833-IV 1839; f. p.; pol.; 184.

17_1_30; Księga aktów urodzonych bełżyckiej rzymskokatolickiej parafii od 1839 do 1844 roku; IV 1839-XII 1844; f. p.; pol.; 204.

17_1_31; Księga aktów urodzonych bełżyckiej rzymskokatolickiej parafii od 1845 do 1851 roku; I 1845-XII 1851; f. p.; pol.; 200.

17_1_32; Księga aktów urodzonych bełżyckiej rzymskokatolickiej parafii od 1852 do 1857 roku; I 1852-XII 1857; f. p.; pol.; 188.

17_1_33; Księga aktów urodzonych bełżyckiej rzymskokatolickiej parafii od 1858 do 1868 roku; I 1858-III 1868; f. p.; pol.; 376.

17_1_34; Księga aktów urodzonych bełżyckiej rzymskokatolickiej parafii od $1 \overline{8} 68$ do 1879 roku; III 1868-VII 1879; f. p.; pol.; 564.

17_1_35; Księga aktów urodzonych bełżyckiej rzymskokatolickiej parafii od $1 \overline{879}$ do 1887 roku; VII 1879-VIII 1887; f. p.; pol.; 468.

17_1_36; Księga aktów urodzonych bełżyckiej rzymskokatolickiej parafii od 1887 do 1893 roku; VIII 1887-V 1893; f. p.; pol.; 458.

17_1_37; Księga aktów urodzonych bełżyckiej rzymskokatolickiej parafii od $1 \overline{8} 93$ do 1897 roku; V 1893-XII 1897; f. p.; pol.; 232.

17_1_38; Księga aktów urodzonych parafii bełżyckiej od 1898 roku do 1903; I 1898-XII 1903; f. p.; ros.; 195. 


\section{Śluby}

17_2_1; Copulatorum ex anno 1606, 1607, 1608, 1609, 1610, 1611 et 1612; X 1605-IV 1612; f. t. ; łac.; 16.

Uwagi: Księga formatu dutki, oprawiona w tekturę. Okładki zniszczone. Na ostatniej stronie wpis dziekana lubelskiego z 27 X 1853 r. potwierdzający kontrolę księgi.

17_2_2; Copulatorum 1630-1699; II 1630-XI 1698; f. t. ; łac.; 420.

Uwagi: Księga formatu dutki, oprawiona w półskórek. Skóra z grzbietu księgi częściowo oberwana. Strony 271 i 293 luzem. Wewnątrz drobne ubytki wyrządzone przez owady, liczne przebarwienia atramentu utrudniające odczytanie wpisów i plamy spowodowane wilgocią. Na ostatniej stronie wpis dziekana lubelskiego z 27 X 1853 r. potwierdzający kontrolę księgi.

17_2 3; Copulatorum ab anno 1699 ad annum 1729; I 1699-II 1729; f. t. ; łac.; 136 .

Uwagi: Księga formatu dutki, oprawiona w półskórek. Na niektórych kartach ubytki (szerokości kilku milimetrów) wyrząadzone przez owady. Str. 115. luzem. Na ostatniej stronie wpis dziekana lubelskiego z 27 X 1853 r. potwierdzający kontrolę księgi.

17_2_4; Copulatorum 1729-1766; V 1729-XI 1760; f. t. ; łac.; 138.

Uwagi: Księga formatu dutki, oprawiona w półskórek. Na okładce oraz niektórych kartach dziury (średnicy kilku milimetrów) wyrządzone przez owady. Wewnątrz plamy spowodowane wilgocią. Na ostatniej stronie wpis dziekana lubelskiego z 27 X 1853 r. potwierdzający kontrolę rejestracji.

17_2_5; Copulatorum 1766-1797; I 1766-II 1797; f. t. ; łac.; 166.

Uwagi: Księga formatu dutki, oprawiona w półskórek. Przednia okładka podarta. Wewnątrz woluminu pojedyncze, kilkumilimetrowe ubytki wyrządzone przez owady, a także plamy spowodowane wilgocią. Na ostatniej stronie wpis dziekana lubelskiego z 27 X 1853 r. potwierdzający kontrolę księgi.

17 2_6; Copulatorum 1797-1825; I 1797-XI 1825; f. a.; łac.; 200.

17_2_7; Księga aktów zaślubionych bełżyckiej rzymskokatolickiej parafii od roku 1826 do 1851 roku; I 1826-II 1851; f. p.; pol.; 260.

17_2_8; Księga aktów zaślubionych bełżyckiej rzymskokatolickiej parafii od roku 1851 do 1862 roku; II 1851-XI 1862; f. p.; pol.; 188.

17 2_9; Księga aktów zaślubionych bełżyckiej rzymskokatolickiej parafii od roku 1863 do 1877 roku; I 1863-XI 1877; f. p.; pol./ ros. V 1869 r.; 230.

17_2_10; Księga aktów zaślubionych bełżyckiej rzymskokatolickiej parafii od roku 1878 do 1890 roku; I 1878-V 1890; f. p.; ros.; 280.

17_2_11; Księga aktów zaślubionych bełżyckiej rzymskokatolickiej parafii od roku 1890 do 1902 roku; VIII 1890-XI 1902; f. p.; ros.; 376.

\section{Zgony}

17_3_1; Mortuorum 1722-1770; III 1722-XII 1764; f. t.; łac.; 134.

Uwagi: Księga formatu dutki, oprawiona w półskórek. Okładki częściowo zniszczone. Strona 9. uszkodzona przy wewnętrznym marginesie, co utrudnia odczytanie wpisów. W księdze odnotowano tylko zgony osób dorosłych. Na ostatniej stronie wpis dziekana lubelskiego z 27 X 1853 r. potwierdzający kontrolę księgi.

17 3_2; Mortuorum 1770-1797; I 1770-XII 1797; f. t.; łac.; 238.

Uwagi: Księga formatu dutki, oprawiona w półskórek. Od 1. do 19. strony wyraźne ślady zawilgocenia i uszkodzenia dolnego marginesu, miejscami przebarwienia atramentu utrudniające od- 
czytanie wpisów. Na ostatniej stronie wpis dziekana lubelskiego z 27 X 1853 r. potwierdzający kontrolę księgi.

17_3_3; Mortuorum 1797-1812; I 1797-XII 1812; f. a.; łac.; 170.

17 3_4; Księga aktów umarłych bełżyckiej rzymskokatolickiej parafii od 1813 do 1825; I 1813-XII 1825; f. p.; łac.; 180.

17 3_5; Księga aktów zmarłych bełżyckiej rzymskokatolickiej parafii od 1826 do 1838 roku; I 1826-III 1838; f. p.; pol; 260.

17 3_6; Księga aktów zmarłych bełżyckiej rzymskokatolickiej parafii od 1838 do 1848 roku; III 1838-XII 1848; f. p.; pol; 194.

17 3_7; Księga aktów zmarłych bełżyckiej rzymskokatolickiej parafii od 1849 do 1855 roku; I 1849-VIII 1855; f. p.; pol.; 196.

17 3_8; Księga miejscowa aktów religijno-cywilnych zejścia parafii bełżyckiej od miesiąca sierpnia 1855 roku po dzień 6 kwietnia 1873; VIII 1855-VIII 1873; f. p.; pol./ros. IV 1868 r.; 372.

17 3_9; Księga aktów zmarłych bełżyckiej rzymskokatolickiej parafii od 1873 do 1884 roku; VIII 1873-V 1884; f. p.; ros.; 377.

17 3_10; Księga aktów zmarłych bełżyckiej rzymskokatolickiej parafii od 1884 do 1892 roku; VII 1884-VIII 1892; f. p.; ros.; 280.

17_3_11; Księga aktów zmarłych bełżyckiej rzymskokatolickiej parafii od 1892 do 1901 roku; VIII 1892-VII 1901; f. p.; ros.; 378.

\section{BISKUPICE}

\section{Chrzty}

31_1_1; Liber baptisatorum 1641-1681; IX 1641-III 1681; f. t.; łac.; 506.

Uwagi: Księga formatu dutki, oprawiona w płótno. Karty 25-29 zniszczone, obszarpane brzegi, a także niewielkie ubytki na dolnym marginesie, utrudniające pełne odczytanie dwóch wpisów. Ubytki w kartach 150-158 uzupełnione papierem. Wyblakły atrament na kartach 244-245. Dolna część karty 251. oderwana. W księdze liczne przebarwienia i plamy spowodowane wilgocią. $\mathrm{Na}$ każdej karcie pieczęć dziekana lubartowskiego. Na końcu księgi notatka dziekana z 14 XI 1852 r. potwierdzająca kontrolę rejestracji.

31_1_2; Urodzonych 1699-1717; I 1699-VIII 1717; f. t.; łac.; 188.

Uwagi: Księga formatu pełnego arkusza, oprawiona w płótno. W kartach 77-79, 85, 90 ubytki. Zniszczone karty 77. i 78. uzupełniono papierem. Na większości stron plamy powstałe wskutek wilgoci. Na każdej karcie pieczęć dziekana lubartowskiego.

31_1_3; Urodzonych 1733-1773; XI 1733-XI 1773; f. t.; łac.; 372.

Uwagi: Księga formatu pełnego arkusza, oprawiona w płótno. Karty opatrzono pieczęcią dziekana lubartowskiego. Na końcu woluminu regestr ochrzczonych mający własną numerację kart (21). Na karcie 187. notatka dziekana z 14 XI 1852 r. potwierdzająca kontrolę rejestracji.

31_1_4; Urodzonych 1773-1796; XI 1772-XI 1796; f. t.; łac.; 160.

Uwagi: Księga formatu pełnego arkusza, oprawiona w płótno. Na grzbiecie okładki niewielkie ubytki materiału. Ubytki w pierwszych dwóch kartach uzupełniono papierem. Na każdej karcie pieczęć dziekana lubartowskiego. Na końcu księgi notatka dziekana z 14 XI 1852 r. potwierdzająca kontrolę rejestracji.

31_1_5; Urodzonych 1792; III 1792-VIII 1796; f. t.; łac.; bns.

Uwagi: Księga formatu pełnego arkusza, oprawiona w płótno. Na karcie 7. plama po rozlanym atramencie. 
31_1_6; Urodzonych 1796-1805; XII 1796-VIII 1809; f. a.; łac.; 200.

31_1_7; Urodzonych 1797-1812; I 1797-X 1812; f. a./f. t. VI 1807 r.; łac.; bns.

31_1_8; Urodzonych 1805-1810; IV 1805-VIII 1810; f. t.; łac.; bns.

31_19; Księga urodzonych 1810; IX 1810-XII 1810; f. p.; pol.; 92.

31_1_10; Księga urodzonych 1811; I 1811-XII 1811; f. p.; pol.; 84.

31_1_11; Księga urodzonych 1812; I 1812-XII 1812; f. p.; pol.; 94.

31_1 12; Księga urodzonych, małżeństw i zmarłych parafii rzymskokatolickiej Biskupice 1813; I 1813-XII 1813; f. p.; pol.; 186.

31_1_13; Księga urodzonych, małżeństw i zmarłych parafii rzymskokatolickiej Biskupice 1814; I 1814-XII 1814; f. p.; pol.; 156.

31_1_14; Księga urodzonych, małżeństw i zmarłych parafii rzymskokatolickiej Biskupice za rok 1815; I 1815-XII 1815; f. p.; pol.; 188.

31_1_15; Księga urodzonych, małżeństw i zmarłych parafii rzymskokatolickiej Biskupice 1816; I 1816-XII 1816; f. p.; pol.; 189.

31 1 16; Księga urodzonych, małżeństw i zmarłych parafii rzymskokatolickiej Biskupice 1817; I 1817-XII 1817; f. p.; pol.; 176.

31_1_17; Księga urodzonych, małżeństw i zmarłych parafii rzymskokatolickiej Biskupice 1818; I 1818-XII 1818; f. p.; pol.; 142.

31_1_18; Księga urodzonych, małżeństw i zmarłych parafii rzymskokatolickiej Biskupice 1819; I 1819-XII 1819; f. p.; pol.; 184.

31_1_19; Księga urodzonych, małżeństw i zmarłych parafii rzymskokatolickiej Biskupice 1820; I 1820-XII 1820; f. p.; pol.; 188.

31_1_20; Księga urodzonych, małżeństw i zmarłych parafii rzymskokatolickiej Biskupice 1821; I 1821-XII 1821; f. p.; pol.; 154.

31_1_21; Księga urodzonych, małżeństw i zmarłych parafii rzymskokatolickiej Biskupice 1822; I 1822-XII 1822; f. p.; pol.; 180.

31_1_22; Księga urodzonych, małżeństw i zmarłych parafii rzymskokatolickiej Biskupice 1823; I 1823-XII 1823; f. p.; pol.; 265.

31_1_23; Księga urodzonych, małżeństw i zmarłych parafii rzymskokatolickiej Biskupice 1824; I 1824-XII 1824; f. p.; pol.; 180.

31_1_24; Księga urodzonych, małżeństw i zmarłych parafii rzymskokatolickiej Biskupice 18125; I 1825-XII 1825; f. p.; pol.; 238.

31_1_25; Księga urodzonych parafii rzymskokatolickiej biskupickiej 1826-1836; I 1826-XII 1835; f. p.; pol.; 492.

31_1_26; Księga urodzonych parafii rzymskokatolickiej biskupickiej 1836-1840; I 1836-XII 1840; f. p.; pol.; 312.

31_1_27; Księga urodzonych parafii rzymskokatolickiej biskupickiej 1841-1851; I 1841-XII 1851; f. p.; pol.; 572.

31_1_28; Księga urodzonych parafii rzymskokatolickiej biskupickiej 1852-1862; I 1852-XII 1862; f. p.; pol.; 526.

31_1_29; Księga urodzonych parafii rzymskokatolickiej biskupickiej 1863-1870 do numeru 38.; I 1863-X 1870; f. p.; pol./ros. V 1868 r.; 379.

31_1_30; [Kniga rodivšichsâ s 1870 goda]; X 1870-XII 1878; f. p.; ros.; 426.

31_1 31; [Kniga rodivšichsâ s 1879 goda]; I 1879-XII 1886; f. p.; ros.; 430.

31_1_32; [Kniga rodivšichsâ s 1887 goda]; I 1887-VII 1893; f. p.; ros.; 464. 
31_1_33; [Kniga rodivšichsâ s 1893 goda]; VIII 1893-XII 1899; f. p.; ros.; 572.

31_1_34; [Kniga rodivšichsâ s 1900 goda]; I 1900-IV 1903; f. p.; ros.; 170.

\section{Śluby}

31_2_1; Liber matrimonium, liber copulatorum 1690-1726; I 1690-I 1726; f. t.; lac.; $144+$ bns.

Uwagi: Księga formatu dutki, oprawiona w płótno, na grzbiecie ubytki materiału. Karta 114. podwójnie foliowana. W górnym rogu karty 115. i 116. plama po atramencie. Dolna część karty 117. oddarta. Wpisy na ostatnich 15 . kartach zostało odwrócone o $180^{\circ}$, zawierają zestawienie imion i nazwisk nowożeńców od 1718 roku. Na stronach liczne przebarwienia i plamy spowodowane wilgocią. Karty opatrzono pieczęcią dziekana lubartowskiego. Na końcu księgi wpis dziekana z 14 XI 1852 r. potwierdzający kontrolę rejestracji.

31_2_2; Ślubna 1726-1767; II 1726-IX 1766; f. t.; łac.; 90.

Uwagi: Księga formatu pełnego arkusza, oprawiona w płótno. Wewnątrz nieliczne plamy i zacieki powstałe wskutek wilgoci. Na każdej karcie pieczęć dziekana lubartowskiego. Na końcu księgi notatka dziekana z 14 XI 1852 r. potwierdzająca kontrolę rejestracji.

31_2_3; Małżeństw 1767-1797; I 1767-XI 1796; f. t.; łac.; 88.

Uwagi: Księga formatu pełnego arkusza, oprawiona w płótno. Wewnątrz nieliczne plamy i zacieki powstałe wskutek wilgoci. Na każdej karcie widnieje pieczęć dziekana lubartowskiego. Na karcie 45. notatka dziekana z 14 XI 1852 r. potwierdzająca kontrolę rejestracji.

31_2_4; Małżeństw 1797-1810; I 1797-VIII 1810; f. a.; łac.; 200.

31_2_5; [Liber metrices copulatorum ab anno 1805]; X 1805-XI 1825; f. t. ; łac.; bns.

312 6; Akta małżeństw 1826-1840; I 1826-XI 1840; f. p.; pol.; 390.

31_2_7; Akta małżeństw 1840-1858; II 1840-XI 1858; f. p.; pol.; 378.

31_2_8; Akta małżeństw 1859-1881; I 1859-XI 1881; f. p.; pol./ ros. V 1868 r.; $4 \overline{7} 2$.

31_2_9; Akty o brakosočetovšihsâ s 1882-1895; I 1882-II 1896; f. p.; ros.; 376.

31_2_10; [Kniga brakosočetavšichsâ s 1896 goda]; II 1896-IX 1909; f. p.; ros.; $2 \overline{1} 1$.

\section{Zgony}

31_3_1; [Liber metrices mortuorum ab anno 1711]; III 1711-VIII 1764; f. t.; łac. $1 \overline{7} 0$

Uwagi: Księga formatu pełnego arkusza, oprawiona w płótno. Ubytki w kartach 4-5 oraz 85. uzupełniono papierem. Karta 61. przecięta wzdłuż prawie na całej długości. Karty opatrzono pieczęcią dziekana lubartowskiego. Na końcu księgi notatka dziekana z 14 XI 1852 r. potwierdzająca kontrolę rejestracji.

31_3_2; Księga zejścia 1765-1796; X 1764 -I 1798; f. t.; łac.; 106.

Uwagi: Księga formatu pełnego arkusza, oprawiona w płótno. Karty opatrzono pieczęcią dziekana lubartowskiego. Na karcie 54. notatka dziekana z 14 XI 1852 r. potwierdzająca kontrolę rejestracji.

31_3_3; Liber mortuorum 1796-1807; VII 1796-VIII 1810; f. a.; łac.; bns.

31_3_4; Zmarłych 1805-1815; IV 1805 -VIII 1815; f. t.; łac.; bns.

31_3_5; Liber mortuorum 1807-1810; XII 1804-VIII 1810; f. a.; łac.; bns.

31_3_6; Zmarłych 1810; IX 1810-XII 1810; f. p.; pol.; 91.

31_3_7; Zmarłych 1811; I 1811-XII 1811; f. p.; pol.; 69. 
31_3_8; Zmarlych 1812; I 1812-XII 1812; f. p.; pol.; 44.

31_3_9; Akta zejścia 1826-1834; I 1826-VII 1834; f. p.; pol.; 397.

31_3_10; Akta zejścia 1834-1848; VIII 1834-IV 1848; f. p.; pol.; 360.

31_3_11; Akta zmarlych 1848-1856; IV 1848-IV 1856; f. p.; pol.; 284.

31_3_12; Akta zmarłych od numeru 64., 1856 do 1881; V 1856-XII 1881; f. p.; pol./ros. V 1868 r.; 646.

31_3_13; Akta ob umerših s 1882 po 1892; I 1882-XII 1892; f. p.; ros.; 362.

31_3_14; [Kniga smerti s 1893 goda]; I 1893-XII 1905; f. p.; ros.; 640.

\section{Chrzty}

\section{BOCHOTNICA}

28_1_1; Liber metrices baptisatorum ab anno 1726 ; I 1726-VI 1783; f. t.; łac.; $3 \overline{9} 4$.

Uwagi: Księga ma format dutki, oprawiona w półskórek. Okładka zniszczona, bez grzbietu, z ubytkami spowodowanymi przez owady. Liczne karty luzem, większość ma też obszarpane górne krawędzie. Wewnątrz plamy atramentu oraz plamy spowodowane wilgocią. Na każdej karcie pieczęć dziekana kazimierskiego. Na końcu księgi wpis dziekana z 23 I 1854 r. potwierdzający kontrolę rejestracji.

28_1_2; Liber metrices baptisatorum ab anno 1783 ad 1797 et mortuorum; VII 1783-III 1800, VII 1783-I 1797; f. t.; łac.; 59.

Uwagi: Księga o wymiarach $39 \times 17 \mathrm{~cm}$, oprawiona w półskórek. Okładka zniszczona, bez grzbietu, z ubytkami spowodowanymi przez owady. Liczne karty luzem, na części z nich plamy spowodowane wilgocią. Na każdej karcie pieczęć dziekana kazimierskiego. Na str. 88 notatka dziekana z 23 I 1854 r. potwierdzająca kontrolę księgi.

28_1_3; [Liber natorum ab anno 1797]; I 1797-XII 1825; f. a.; łac.; 134.

28_1_4; Liber natorum, copulatorum et mortuorum ab anno 1804; IX 1804-XII $1 \overline{8} 11$; f. t.; łac.; bns.

28_1_5; Akta cywilne gminy bochotnickiej w roku 1810 od 21 września; VIII 1810-XII 1810; f. p.; pol.; 28.

28_1_6; [Księga urodzeń, małżeństw i zgonów od 1811 roku].; I 1811-XII 1811; f. p.; pol.; 97.

28_1_7; [Księga urodzeń, małżeństw i zgonów od 1812 roku]; I 1812-XII 1812; f. p.; pol.; 104.

28_1_8; [Księga urodzeń, małżeństw i zgonów od 1813 roku]; I 1813-XII 1813; f. p.,; pol.,; 80 .

28_1_9; [Księga urodzeń, małżeństw i zgonów od 1814 roku]; I 1814-XII 1814; f. p.; pol.; 92 .

28_1_10; [Księga urodzeń, małżeństw i zgonów od 1815 roku]; I 1815-XII 1815; f. p.; pol.; 42.

28_1_11; [Księga urodzeń, małżeństw i zgonów od 1816 roku ]; I 1816-XII 1816 ; f. p.; pol.; 44

28_1_12; Akta cywilne gminy Nałęczów z roku 1817; I 1817-XII 1817; f. p.; pol.; $4 \overline{6}$.

28_1_13; Akta cywilne gminy nałęczowskiej roku 1818; I 1818-XII 1818; f. p.; pol.; 36 . 
28_1_14; Akta cywilne urodzonych, zaślubionych, zmarłych w gminie bochotnickiej czyli Nałęczów z roku 1819; I 1819-XII 1819; f. p.; pol.; 54.

28_1_15; [Księga urodzeń, małżeństw i zgonów od 1820 roku]; I 1820-XII 1820; f. p.; pol.; bns.

28 1_16; [Księga urodzeń, małżeństw i zgonów od 1821 roku]; I 1816-XII 1816 ; f. p.; pol.; 44 .

28_1_17; Rok 1822, akta urodzenia, zapowiedzi, małżeństw i zejścia w gminie bochotnickiej; I 1822-XII 1822; f. p.; pol.; 66.

28_1_18; [Księga urodzeń, małżeństw i zgonów od 1823 roku]; I 1823-XII 1823; f. p.; pol.; 86 .

281 19; [Księga urodzeń, małżeństw i zgonów od 1824 roku]; I 1824-XII 1824; f. p.; pol.; 82 .

28_1_20; [Księga urodzeń, małżeństw i zgonów od 1825 roku]; I 1825-XII 1825; f. p.; pol.; 88 .

28_1_21; Akta urodzin parafii bochotnickiej od 1. stycznia 1826 roku rozpoczęte.; I 1826-XII 1843; f. p.; pol.; 283.

28_1_22; Księga urodzonych parafii bochotnickiej od 1844 do 1865 roku; I 1844XII 1865; f. p.; pol.; 452.

28_1_23; Kniga aktov o rodivšihsâ katoličeskago prihoda Bohotnica, načinaetsâ ot 1866 goda do 1882 goda; I 1866-IV 1883; f. p.; pol. / ros. II 1868 r.; 370.

28 1_24; Kniga aktov o rodivšihsâ katoličeskago prihoda Bohotnica, načinaetsâ ot 1883 do 1895 goda; IV 1883-XII 1893; f. p.; ros.; 196.

28_1_25; Kniga o rodivšihsâ 1894 po 1900 god; I 1894-XII 1900; f. p.; ros.; 354.

\section{Śluby}

$28 \_2$ 1; [Liber metrices copulatorum ab anno 1728]; I 1728-XI 1796; f. t.; łac.; 208.

Uwagi: Księga formatu dutki, oprawa zniszczona, zachowała się tylko część tylnej okładki. Liczne karty luzem, na części z nich ubytki wyrządzone przez owady. Na marginesach str. 52-53 ślady kleju przebijające na inne karty. Na każdej karcie pieczęć dziekana kazimierskiego. Na ostatniej karcie notatka dziekana z 23 I 1854 r. potwierdzająca kontrolę rejestracji.

282 2; [Liber natorum ab anno 1797]; I 1797 -XI 1825; f. a.; łac.; 134.

28_2_3; Akta małżeństw parafii bochotnickiej od dnia 1. stycznia 1826 roku rozpoczęte; I 1826-XI 1858; f. p.; pol.; 197.

28 2_4; Akta małżeństw w parafii rzymskokatolickiej Bochotnica od roku 1859; II 1859-XI 1882; f. p.; pol. / ros. II 1868 r.; 192.

28_2_5; [Kniga brakosočetavšichsâ s 1883 goda]; I 1883-XI 1899; f. p.; ros.; 138. 28_2_6; [Kniga brakosočetavšichsâ s 1900 goda]; I 1900-XI 1919; f. p.; ros./ pol. I 1916 r.; 382.

\section{Zgony}

28_3_1; [Liber metrices mortuorum ab anno 1726]; II 1726-XI 1783; f. t.; łac.; $1 \overline{8} 0$.

Uwagi: Księga formatu dutki, oprawiona w półskórek. Okładka zniszczona, bez grzbietu, część kart luzem z plamami spowodowanymi wilgocią. Na każdej karcie pieczęć dziekana kazimierskiego. Na str. 179 notatka dziekana z 23 I 1854 r. potwierdzająca kontrolę wpisów. 
28_3_2; [Liber mortuorum ab anno 1797]; I 1797-XII 1825; f. a.; łac.; 152.

28_3_3; [Księga zgonów od roku 1826]; I 1826-XII 1844; f. p.; pol.; 197.

28_3_4; Księga gruntowa do zapisywania akt zejścia czyli śmierci parafii bochotnickiej od roku 1845; I 1845-XII 1867; f. p.; pol.; 273.

28 3_5; Księga miejscowa akt zmarłych parafii Bochotnica od roku 1868 do roku 1883; I 1868-XII 1883; f. p.; pol. / ros. II 1868 r. ; 282.

283 6; [Kniga smerti s 1884 goda ]; I 1884-XII 1896; f. p.; ros.; 272.

28_3_7; Unikat aktov graždanskago sostoâniâ prihoda Bohotnica o umerših w 1897 godu.; I 1897-XI 1906; f. p.; ros.; 382.

\section{BYCHAWA}

\section{Chrzty}

25_1_1; Liber 1. baptisatorum ab anno 1629; VIII 1617-IV 1716; f. t.; łac.; 352.

Uwagi: Księga formatu dutki,oprawiona jest w półskórek. Większość kart nosi ślady zawilgocenia. Dolne brzegi str. 27-38 są obszarpane. Strony 117-141 w dolnej części, przy wewnętrznym marginesie, mają ubytki w kształcie klinu o powierzchni ok. $4 \mathrm{~cm}^{2}$ każdy; dodatkowo, część kart włożona luzem, chronologia wpisów zakłócona. Księga powstała w wyniku połączenia kart z różnych woluminów. $\mathrm{Na}$ str. 349-351 roczne podsumowania odnotowanych chrztów. Na każdej karcie pieczęć dziekana chodelskiego. Na str. 351 notatka dziakana z 22 XII 1853 r. potwierdzająca kontrolę księgi.

25_1_2; Liber 2. baptisatorum ab anno 1665 usque ad annum 1691; X 1665-III 1691 ; f. t.; łac.; 216.

Uwagi: Księga formatu dutki, oprawiona w półskórek. Karty 1-2, 4, 6-8 i 15 mają znaczne ubytki, które uniemożliwiają odczytanie kilkunastu wpisów. Dodatkowo na kartach tych liczne plamy spowodowane wilgocią. Od str. 16 do 62 poodrywane dolne rogi, utrudnia to poprawne odczytanie wpisów. Od 195 str. do 212 str. na obrzeżach kart drobne ubytki, które uzupełniono pergaminowym, zielonym papierem. Na końcu księgi dla poszczególnych lat zestawiono sumaryczne dane o liczbie udzielonych chrztów. Na każdej karcie pieczęć dziekana chodelskiego. Na końcu woluminu notatka dziekana z 22 XII 1853 r. potwierdzająca kontrolę księgi.

25_1_3; Liber 3. baptisatorum ab anno 1717 usque ad annum 1746; I 1717-XII 17̄46; f. t.; łac.; 296.

Uwagi: Księga formatu pełnego arkusza, oprawiona w półskórek. Wewnątrz przebarwienia powstałe wskutek wilgoci. Na str. 295 i 296 znajduje się sumaryczne zestawienie odnotowanych w księdze chrztów. Każda karta zoopatrzona w pieczęć dziekana chodelskiego. Na końcu woluminu notatka dziekana z 22 XII 1853 r. potwierdzająca kontrolę księgi.

25_1_4; Liber 5. baptisatorum ab anno 1763 usque ad annum 1770 et ab anno $1 \overline{7} 47$ usque 1751; XII 1746-XII 1770; f. t.; łac.; 128.

Uwagi: Księga formatu pełnego arkusza, oprawiona w półskórek. Strony 1-4 i 91-126 mają mniejszy format aniżeli pozostałe. Wewnątrz liczne ciemne plamy spowodowane wilgocią. Chronologia wpisów zaburzona. Na str. 127-128 umieszczono sumaryczne zestawienie odnotowanych chrztów. Na każdej karcie widnieje pieczęć dziekana chodelskiego. Na końcu woluminu notatka dziekana z 22 XII 1853 r. potwierdzająca kontrolę księgi.

25_1_5; Księga 6. urodzonych z roku 1770; I 1771-X 1797; f. t.; łac.; 302.

Uwagi: Księga ma format pełnego arkusza, oprawiona w półskórek. Wewnątrz liczne plamy powstałe wskutek wilgoci, są one szczególnie widoczne na obrzeżach kart. Trzy końcowe karty mają 
oderwane dolne marginesy, ubytek na ostatniej karcie został uzupełniony białym kredowym papierem. Na stronach 361-362 umieszczono sumaryczne zestawienia chrztów odnotowanych w księdze. Na każdej karcie pieczęć dziekana chodelskiego. Na końcu woluminu notatka dziekana z 22 XII 1853 r. potwierdzająca kontrolę księgi.

25_1_6; Księga 7. urodzonych kościoła Bychawy od roku 1797 do 1810; X 1797XII 1810; f. a.; łac.; 240.

25_1_7; Księga aktów cywilnych urodzonych, zaślubionych i zmarłych od dnia 16 września 1810 do dnia 31 grudnia tegoż roku parafii bychawskiej; IX 1810XII 1810 ; f. p.; pol.; 63.

25_1_8; Księga aktów cywilnych urodzony i zmarłych w roku 1811, zaślubionych i zmarlych w roku 1811 Starej Wsi; I 1811-XII 1811; f. p.; pol.; bns.

25 1_9; [Liber natorum ab anno1811]; I 1811-XII 1836; f. a.; łac.; bns.

25_1_10; Księga aktów cywilnych urodzonych z roku 1810, urodzonych, zaślubionych i zmarłych z roku 1811 parafii bychawskiej; IX 1810-XII 1810 I 1811-XII 1811 I 1811-XI 1811 I 1811-XII 1811; f. p.; pol.; 236.

25_1_11; Księga aktów cywilnych urodzonych, zaślubionych i zmarłych od dnia $1 \overline{9}$ stycznia do dnia 31 grudnia 1812 roku parafii bychawskiej; I 1812-XII 1812, I 1812-XII 1812, I 1812-XII 1812; f. p.; pol.; 188.

25_1_12; Księga aktów cywilnych urodzonych od dnia 19 stycznia do dnia 31 grudnia 1812 roku, zaślubionych i zmarłych od dnia 11 stycznia do dnia 31 grudnia 1813 roku Starej Wsi; I 1813-XII 1813, I 1813-XII 1813, I 1813-XII 1813 ; f. p.; pol.; 49.

25_1_13; Księga aktów cywilnych urodzonych, zaślubionych i zmarłych od dnia 1 stycznia 1814 roku do dnia 31 grudnia tego roku parafii bychawskiej; I 1814-XII 1814, I 1814-XII 1814, I 1814-XII 1814 ; f. p.; pol.; 180.

25_1_14; Księga aktów cywilnych urodzonych od dnia 3 stycznia do dnia 31 grudnia 1813 roku, urodzonych, zaślubionych i zmarłych od dnia 18 stycznia 1814 roku do dnia 31 grudnia 1816 roku Starej Wsi; I 1814-XII 1816; f. p.; pol.; 84 .

25_1_15; Księga aktów cywilnych urodzonych, zaślubionych i zmarłych z roku 1815 parafii bychawskiej; I 1815-V 1816, I 1815-IX 1816, I 1815-V 1816; f. p.; pol.; 170.

25_1_16; Księga Bychawy z roku 1816 i 1817; VI 1816-XII 1817, X 1816-V 1817, VI 1816-XII 1817; f. p.; pol.; 179.

25_1_17; Księga Starej Wsi 1817; I 1817-XII 1821, II 1817-XI 1821, V 1817-II $1 \overline{821}$; f. p.; pol.; 82 .

25_1_18; Księga aktów cywilnych urodzonych, zaślubionych i zmarłych od dnia 1 stycznia do dnia 31 grudnia 1818 roku parafii bychawskiej; I 1818-XII 1818, I 1818-XII 1818, I 1818-XII 1818; f. p.; pol.; 92.

25_1_19; Książka aktów stanu cywilnego należąca do gminy Stara Wieś na rok $1 \overline{8} 18$, urodzin, małżeństw i zejścia; I 1818-XII 1818, I 1818-XI 1818, I 1818XII 1818; f. p.; pol.; 32.

25_1_20; [Księga urodzeń, małżeństw i zgonów od 1820 roku]; I 1820-XII 1820 I 1820-XII 1820, I 1820-XII 1820; f. p.; pol.; 136. 
25_1_21; Księga aktów stanu cywilnego urodzin, ślubów i zgonów na rok 1821 należąca do kościoła bychawskiego 1821; I 1821-XII 1821 I 1821-XI 1821 I 1821-XII 1821; f. p.; pol.; 100.

25_1_22; Księga aktów urzędnika stanu cywilnego urodzin, małżeństw i zejścia parafii gminy bychawskiej na rok 1822; I 1822-XII 1822, I 1822-XI 1822, I 1822-XII 1822; f. p.; pol.; 90.

25 1_23; [Księga urodzeń, małżeństw i zgonów od 1823 roku]; I 1823-XII 1825; f. p.; pol.; 305 .

25_1_24; Księga aktów cywilnych urodzonych, zaślubionych i zmarłych od 1 stycznia 1823 roku do dnia 31 grudnia 1825 Starej Wsi; I 1823-XII 1825, I 1823-XII 1825, I 1823-XII 1825; f. p.; pol.; 130.

25_1_25; Unikat urodzonych od 1 I 1826 roku numeru 1. do 28 XII 1834 roku numeru 132. rzymskokatolickiej parafii Bychawa; I 1826-XII 1834; f. p.; pol.; 372.

25_1_26; Unikat urodzonych od 3 I 1835 numeru 1. do 19 IV 1840 roku numeru 72. rzymskokatolickiej parafii Bychawa; I 1835-IV 1840; f. p.; pol.; 280.

25_1_27; Unikat urodzonych od 24 IV 1840 roku numeru 73. do 10 VII 1844 roku numeru 87. rzymskokatolickiej parafii Bychawa; IV 1840-VII 1844; f. p.; pol.; 376 .

25_1_28; Unikat urodzonych od dnia 11 VII 1844 roku /88 do dnia 25 XI 1847 roku /138, rzymskokatolickiej parafii Bychawa; VII 1844-XI 1847; f. p.; pol.; 274.

25 1_29; Unikat urodzonych od 28 XI 1847 numeru 139. do 17 IV 1851 roku numeru 70. rzymskokatolickiej parafii Bychawa; XI 1847-IV 1851; f. p.; pol.; 274.

25_1_30; Unikat urodzonych od 17 IV 1851 roku numeru 71. do 1 X 1855 roku numeru 106. rzymskokatolickiej parafii Bychawa; IV 1851-X 1855; f. p.; pol.; 372.

25_1_31; Unikat urodzonych od 1 X 1855 roku numeru 107. do 14 XI 1859 roku numeru 152. rzymskokatolickiej parafii Bychawa; X 1855-XI 1859; f. p.; pol.; 360.

25_1_32; Unikat urodzonych od 16 XI 1859 roku, numeru 153. do 20 XI 1862 roku numeru 182. rzymskokatolickiej parafii Bychawa; XI 1859-XI 1862; f. p.; pol.; 374 .

25_1_33; Unikat urodzonych od 20 XI 1862 roku numeru 183. do 1 I 1865 roku numeru 138. rzymskokatolickiej parafii Bychawa; XI 1862-XII 1864; f. p.; pol.; 278.

25_1_34; Unikat urodzonych od 1 I 1865 numeru 1. do 25 IX 1867 roku numeru 167. rzymskokatolickiej parafii Bychawa; I 1865-IX 1867; f. p.; pol.; 372.

25_1_35; Unikat urodzonych 29 IX 1867 roku numeru 168.-9 VIII 1870 roku numeru 134. rzymskokatolickiej parafii Bychawa; IX 1867-VIII 1870; f. p.; pol./ros. IV 1868 r.; 370.

25_1_36; Unikat urodzonych od 11 VIII 1870 numeru 135. do 12 VI 1873 roku numeru 113. rzymskokatolickiej parafii Bychawa; VIII 1870-VII 1873; f. p.; ros.; 372 . 
25_1_37; Unikat urodzonych od dnia 15 VI 1873 roku /114 do dnia 30 XII 1879 /292 rzymskokatolickiej parafii Bychawa; VII 1873-XII 1879; f. p; ros.; 370.

25_1_38; Unikat urodzonych od dnia 1 I 1880 numeru 1. do dnia 30 XII 1888 roku numeru 318. rzymskokatolickiej parafii Bychawa; XII 1880-XII 1888; f. p.; ros.; 474.

25_1_39; Unikat urodzonych od 1 I 1889 do 19 IX 1897; I 1889-IX 1896; f. p.; ros.; 558 .

25_1_40; Unikat urodzonych od 19 IX 1897 roku numeru 261. do 14 IV 1902 roku numeru 136. rzymskokatolickiej parafii Bychawa; IX 1897-IV 1902; f. p.; ros.; 480.

\section{Śluby}

25_2_1; Liber 8. copulatorum ab anno 1711 usque ad annum 1741; I 1711-XI $1 \overline{7} 41$; f. t.; łac.; 136.

Uwagi: Księga ma format dutki, oprawiona w półskórek. Na str. 80-81 zapisy zostały przekreślone, a str. 95-102 mają oberwany górny margines. Ostatnia karta księgi zawiera roczne podsumowania udzielonych ślubów. Każdą kartę ostemplowano pieczęcią dziekana chodelskiego. Na końcu woluminu notatka dziekana z 22 XII 1853 r. potwierdzająca kontrolę księgi.

25_2_2; Liber 9. copulatorum ab anno 1752 usque ad annum 1770; I 1752-VII 1770; f. t.; łac.; 74.

Uwagi: Księga ma format dutki, oprawiona w półskórek. Wewnątrz woluminu liczne plamy spowodowane przez wilgoć. Na str. 72-73 roczne podsumowania liczby udzielonych ślubów. Na każdej karcie pieczęć dziekana chodelskiego. Na końcu woluminu notatka dziekana z 22 XII 1853 r. potwierdzająca kontrolę księgi.

25_2_3; [Liber metrices copulatorum ab anno 1771]; I 1771-X 1797; f. t.; łac.; 132 .

Uwagi: Księga formatu dutki, oprawiona w półskórek. Okładki i blok księgi oddzielają się, widoczne są scyzury. Księga w kilku miejscach rozkleja się. Na str. 131-132 umieszczono roczne podsumowania udzielonych ślubów. Na każdej karcie pieczęć dziekana chodelskiego. Na końcu woluminu notatka dziekana z 22 XII 1853 r. potwierdzająca kontrolę księgi.

25_2_4; Księga 11. zaślubionych Kościoła Bychawa w roku 1797-1810; X 1797XI 1837; f. a.; łac.; 202.

25_2_5; Akta zaślubionych parafii rzymskokatolickiej Bychawa z 1826 roku po 1843 rok; I 1826-V 1843; f. p.; pol.; 372.

25_2_6; [Księga małżeństw od 1843 roku]; V 1843-VI 1856; f. p.; pol.; 378.

25 2_7; Unikat zaślubionych od 8 VI 1856 roku numeru 19. do 10 II 1861 roku numeru 17. rzymskokatolickiej parafii Bychawa; VI 1856-II 1861; f. p.; pol.; 178.

25_2_8; Unikat zaślubionych od 10 II 1861 numeru 18. do 26 XI 1865 roku numeru 59. rzymskokatolickiej parafii Bychawa; II 1861-XII 1865; f. p.; pol.; 276

25_2_9; Unikat zaślubionych od dnia 21 I 1866 roku numeru 1. do dnia 26 XI $1 \overline{8} 74$ roku numeru 39. rzymskokatolickiej parafii Bychawa; I 1866-XI 1874; f. p.; pol./ros. V 1868 r.; 324.

25_2_10; Unikat zaślubionych od dnia 17 I 1875 /1 do dnia 24 XI 1889 /56. rzymsk̄okatolickiej parafii Bychawa; I 1875-XI 1889; f. p.; ros.; 274. 
25_2_11; Unikat zaślubionych od dnia 5 I 1890 roku numeru 1. do dnia 25 XI $1 \overline{9} 02$ roku numeru 48. rzymskokatolickiej parafii Bychawa; I 1890-XI 1902; f. p.; ros.; 276.

\section{Zgony}

253 1; Akta zmarłych od 1771 do 1797; I 1771-X 1797; f. t.; łac.; 180.

Uwagi: Księga formatu dutki, oprawiona w skórę. Blok księgi odkleja się od okładek. Str. 5-13 na wewnętrznym marginesie mają ślady po taśmie samoprzylepnej, dodatkowo wypadają ze sklejki. Wewnątrz liczne przebarwienia powstałe wskutek działania wilgoci. Na ostatniej karcie roczne sumaryczne zestawienia udzielonych ślubów. Każda karta została zaopatrzona w pieczęć dziekana chodelskiego. Na końcu woluminu notatka dziekana z 22 XII 1853 r. potwierdzająca kontrolę księgi.

25 3_2; Księga 14. zmarłych kościoła bychawskiego zaczęta od 1. aktu 17971810; XI 1797-III 1811; f. a.; łac.; 210.

25_3_3; Akta zmarłych od 1811 roku do 1825 roku, rzymskokatolickiej parafii Bychawa; I 1811 -XI 1831; f. a.; łac.; bns.

25_3_4; Unikat zmarłych od 1 I 1826 numeru 1. do 14 IV 1840 roku numeru 58. rzymskokatolickiej parafii Bychawa; I 1826-IV 1840; f. p.; pol.; 374.

25_3_5; Unikat zmarłych od 14 IV 1840 roku numeru 59. do 18 II 1845 roku numeru 25. rzymskokatolickiej parafii Bychawa; IV 1840-II 1845; f. p.; pol.; 282.

25 3_6; Unikat zmarłych od 28 II 1845 roku numeru 26. do 23 VII 1850 roku numeru 86. rzymskokatolickiej parafii Bychawa; II 1845-VII 1850; f. p.; pol.; 278.

25_3_7; Unikat zmarłych od 23 VII 1850 roku numeru 157. do 25 VIII 1854 roku numeru 79. rzymskokatolickiej parafii Bychawa; VII 1850-VIII 1854; f. p.; pol.; 282.

25_3_8; Unikat zmarłych od 25 VIII 1854 roku numeru 157. do 25 VIII 1859 roku numeru 79. rzymskokatolickiej parafii Bychawa; VIII 1854-VIII 1859; f. p.; pol.; 372 .

25_3_9; Unikat zmarłych od 25 VIII 1859 roku numeru 80. do 21 IV 1866 roku numeru 48. rzymskokatolickiej parafii Bychawa; VIII 1859-IV 1866; f. p.; pol.; 374 .

25_3_10; Unikat zmarłych od 27.04. 1866 roku numeru 49. do 31. 12. 1871 roku numeru 155. rzymskokatolickiej parafii Bychawa ; IV 1866-XII 1871; f. p.; pol./ ros. IV 1868 r.; 326.

25_3_11; Unikat zmarłych od 3 I 1872 roku numeru 1. do 31 XII 1881 numeru 188. rzymskokatolickiej parafii Bychawa; I 1872 -VI 1882; f. p.; ros.; 328.

25_3_12; Unikat zmarłych od 25 V/5 VI 1882 roku numeru 106. do 15/27 XI 1894 roku numeru 182. rzymskokatolickiej parafii Bychawa; VI 1882-XI 1894; f. p.; ros.; 380.

25_3_13; Unikat zmarłych od 27 XI 1894 numeru 183. do 29 II 1904 numeru 54. rzymskokatolickiej parafii Bychawa; XI 1894-II 1904; f. p.; ros.; 472. 


\section{BYCHAWKA}

\section{Chrzty}

13_1_1; [Liber metrices baptisatorum ab anno 1787]; VIII 1787-XII 1800; f. t.; łac.; 53.

Uwagi: Księga formatu $36 \times 16 \mathrm{~cm}$, oprawiona w skórę, grzbiet oklejono płótnem. Wewnątrz zabrudzenia oraz plamy spowodowane wilgocią. W górnym rogu każdej karty widnieje pieczęć dziekana chodelskiego. Na końcu księgi notatka dziekana z 21 XII 1853 r. potwierdzająca kontrolę księgi.

13_1_2; Liber natorum in parochialem in Bychawka ab anno 1797; IX 1797-XII 1815 ; f. a.; łac.; 208.

13_1_3; Księga akt cywilnych urodzenia, uznania, przysposobienia, zapowiedzi, małżeństwa i zejścia w parafii Bychawce, sporządzona w roku 1810; IX 1810XII 1810; f. p.; pol.; 164.

13_1_4; Księga akt cywilnych urodzenia, uznania, przysposobienia, zapowiedzi, małżeństwa i zejścia w parafii Bychawce, sporządzona w roku 1811; I 1811XII 1811; f. p.; pol.; 254.

13_1_5; [Księga urodzeń, małżeństw i zgonów od 1812 roku]; I 1812-XII 1812; f. p.; pol.; 252 .

13_1_6; [Księga urodzeń, małżeństw i zgonów od 1813 roku]; I 1813-XII 1813; f. p.; pol.; 182 .

13_1_7; [Księga urodzeń, małżeństw i zgonów od 1814 roku]; I 1814-XII 1814; f. p.; pol.; 192.

13_1_8; [Księga urodzeń, małżeństw i zgonów od 1815 roku]; I 1815-XII 1815; f. p.; pol.; 203.

13_1_9; Liber natorum in parochia Bychawka ab anno 1816 ad annum 1827; I 1816-IX 1827; f. a. rysowany; łac.; bns.

13_1_10; [Księga urodzeń, małżeństw i zgonów od 1816 roku]; I 1816-XII 1816; f. p.; pol.; 132 .

13_1_11; Księga akt cywilnych urodzenia, uznania, przysposobienia, zapowiedzi, małżeństwa, zejścia w parafii Bychawka 1817; I 1817-XII 1817; f. p.; pol.; 140.

13_1_12; Księga akt cywilnych urodzenia, uznania, przysposobienia, zapowiedzi, małżeństwa, zejścia w parafii Bychawka na rok 1818; I 1818-XII 1818; f. p.; pol.; 160.

13_1_13; [Księga urodzeń, małżeństw i zgonów od 1819 roku ]; I 1819-XII 1819; f. p.; pol.; 168 .

13_1_14; [Księga urodzeń, małżeństw i zgonów od 1820 roku]; I 1820-XII 1820; f. p.; pol.; 184 .

13_1_15; [Księga urodzeń, małżeństw i zgonów od 1821 roku]; I 1821-XII 1821; f. p.; pol.; 170 .

13_1_16; [Księga urodzeń, małżeństw i zgonów od 1822 roku]; I 1822-XII 1822; f. p.; pol.; 184 .

13_1_17; [Księga urodzeń, małżeństw i zgonów od 1823 roku]; I 1823-XII 1823; f. p.; pol.; 170 . 
13_1_18; [Księga urodzeń, małżeństw i zgonów od 1824 roku]; I 1824-XII 1824; f. p.; pol.; 208.

13_1_19; [Księga urodzeń, małżeństw i zgonów od 1825 roku]; I 1825-XII 1825; f. p.; pol.; 208.

13_1_20; [Księga urodzeń, małżeństw i zgonów od 1826 roku]; I 18126-XII 1832; f. p.; pol.; 284.

13_1_21; Mestnaâ kniga aktov graždanskago sostoâniâ o roždenii rimsko-katoličeskago prihoda Byhavka ot 1833 po 1840 god; I 1833-XII 1839; f. p.; pol.; 272.

13_1_22; Mestnaâ kniga aktov graždanskago sostoâniâ o roždenii rimsko-katoličeskago prihoda Byhavka s 1840 po 1851 god.; I 1840-XII 1850; f. p.; pol.; 360.

13_1_23; [Księga urodzeń od 1851 roku]; I 1851-XII 1863; f. p.; pol.; 380.

13_1_24; Mestnaâ kniga aktov graždanskago sostoâniâ o roždenii rimsko-katoličeskago prihoda Byhavka s 1864 po 1878 god; I 1864-XII 1877; f. p.; pol./ ros. IV 1868 r.; 380.

13_1_25; Mestnaâ kniga aktov graždanskago sostoâniâ o brakosočetanii rimskokatoličeskago prihoda Byhavka s 1878 po 1889 god.; I 1878-IV 1889; f. p.; ros.; 380 .

13_1_26; Mestnaâ kniga aktov graždanskago sostoâniâ o roždenii rimsko-katoličeskago prihoda Byhavka s 1889 po 1894 god; IV 1889-III 1895; f. p.; ros.; 282.

13_1_27; [Księga urodzeń od 1895 roku]; III 1895-II 1902; f. p.; ros.; 474.

\section{Śluby}

13_2_1; [Liber metrices copulatorum ab anno 1787]; IX 1787-IX 1797; f. t.; łac.; $2 \overline{1}$.

Uwagi: Księga formatu pełnego arkusza, oprawiona w skórę. Wewnątrz zabrudzenia oraz plamy spowodowane wilgocią Część kart z pieczęcią dziekana chodelskiego. Na 21 str. notatka dziekana z 21 XII 1853 r. potwierdzająca kontrolę księgi.

13_2_2; Liber copulatorum [ab anno 1797]; XI 1797-X 1827; f. a.; łac.; 200.

13_2_3; [Księga małżeństw od 1826 roku]; I 1826-VI 1841; f. p.; pol.; 280.

13_2_4; Mestnaâ kniga aktov graždanskago sostoâniâ o brakosočetanii rimskokatoličeskago prihoda Byhavka s 1841 po 1863 god; VI 1841-XII 1862; f. p.; pol.; 280.

13_2_5; Mestnaâ kniga aktov graždanskago sostoâniâ o brakosočetanii rimskokatoličeskago prihoda Byhavka s 1863 po 1889 god; I 1863-V 1889; f. p.; pol./ros. IX 1868 r.; 280.

13_2_6; Mestnaâ kniga aktov graždanskago sostoâniâ o brakosočetanii rimskokatoličeskago prihoda Byhavka s c 1889 po 1902 god; V 1889-V 1902; f. p.; ros.; 284. 


\section{Zgony}

13_3_1; Księga 1. metryk zejścia zaczyna się od roku 1787, a kończy 1797; II 1787-IX 1797; f. t.; łac.; 29.

Uwagi: Księga formatu pełnego arkusza, oprawiona w skórę. Na brzegach kart liczne zacieki. Każda z kart opatrzona jest pieczęcią dziekana chodelskiego. Na końcu księgi notatka dziekana z 21 XII 1853 r. potwierdzająca kontrolę księgi.

13_3_2; [Liber mortuorum ab anno 1797]; X 1797-IX 1827; f. a. rysowany od 1818; łac.; 224.

13 3_3; [Księga zgonów od 1826 roku]; I 1826-XI 1833; f. p.; pol.; 280.

13_3_4; Mestnaâ kniga aktov graždanskago sostoâniâ o umerših rimsko-katoličeskago prihoda Byhavka s 1833 po 1850 god; XI 1833-XII 1849; f. p.; pol.; 292.

13_3_5; [Księga zgonów od 1850 roku]; I 1850-XII 1868; f. p.; pol./ ros. IV 1868 r.; 382 .

13_3_6; Mestnaâ kniga aktov graždanskago sostoâniâ o umerših rimsko-katoličeskkago prihoda Byhavka s 1869 po 1894 god; I 1869-XII 1894; f. p.; ros.; 444.

13_3_7; Mestnaâ kniga aktov graždanskago sostoâniâ o umerših rimsko-katoličeskago prihoda Byhavka s 1895 po 1906; I 1895-VIII 1906; f. p.; ros.; 472.

\section{Źródła}

\section{BIBLIOGRAFIA}

Archiwum Archidiecezji Lubelskiej (AAL)

syg. Rep. 60, VI, nr 1. Akta Konsystorza Generalnego Diecezji Lubelskiej. Wykaz statystyczny o ruchu ludności w parafiach dzisiejszych guberni lubelskiej od najdawniejszych czasów do $1901 \mathrm{r}$.

Archiwa parafialne

Księgi metrykalne - patrz Aneks.

Archiwum Państwowe w Lublinie (APL)

syg. 106/56, Akta parafii rzymskokatolickiej w Niedrzwicy 1675-1802.

\section{Opracowania}

Biernat Andrzej, Księgi metrykalne w archiwach państwowych, ,Archiwa Biblioteki i Muzea Kościelne”, 75 (2001) s. 65-74.

Gawrysiakowa Janina, Grupy wyznaniowe ludności w Lubelskiem w XIX wieku, Lublin 1992.

Gawrysiakowa Janina, Zasoby archiwów parafialnych, ziemia lubelska, parafie rzymskokatolickie. Stan na 1 II 1980 r., ,,Przeszłość Demograficzna Polski”, 13 (1981) s. 119-124.

Gieysztorowa Irena, Badania demograficzne na podstawie metryk parafialnych, „Kwartalnik Historii Kultury Materialnej”, 10 (1962) s. 103. 
Hoszowski Stanisław, Dynamika rozwoju zaludnienia Polski w epoce feudalnej (X-XVIII w.), ,Roczniki Dziejów Społecznych i Gospodarczych”, 13 (1951) s. 137-198.

Hoszowski Stanisław, Sułowski Zygmunt, Ewidencja ruchu naturalnego ludności oparta na dawnych metrykach parafialnych, „Przeszłość Demograficzna Polski”, 4 (1971) s. 3-20.

Kula Witold, Problemy i metody historii gospodarczej, Warszawa 1963.

Kula Witold, Stan i potrzeby badań nad demografia historyczna dawnej Polski (do poczatków XIX w.), ,, Roczniki Dziejów Społecznych i Gospodarczych”, 13 (1951) s. 23-110.

Kumor Bolesław, Dzieje diecezji krakowskiej do roku 1795, Kraków 2002.

Rachwał Piotr, Historyczna rejestracja metrykalne $w$ archiwach parafialnych $w$ Lubelskiem, w: Retrospekcja i ochrona dziedzictwa kulturowego, red. S. Kowalska, D. Wańka, Poznań-Kalisz 2015, s. 150-164.

Rachwał Piotr, Księgi metrykalne z czasów zaboru austriackiego $w$ archiwach parafialnych w Lubelskiem - regulacje prawne, stan zachowania, „Rocznik Lubelskiego Towarzystwa Genealogicznego", 6 (2014/2015) s. 306-325.

Rachwał Piotr, Staropolskie księgi metrykalne w archiwach parafialnych archidiecezji lubelskiej, „Kwartalnik Historii Kultury Materialnej”, 63 (2015) nr 4, s. 585-601.

Stopniak Franciszek, Archiwa parafialne dekanatu lubelskiego, „Archiwa Biblioteki i Muzea Kościelne", 9 (1964) s. 5-19.

Sułowski Zygmunt, O właściwa metodę wykorzystywania metryk kościelnych dla badań demograficznych, „Kwartalnik Historii Kultury Materialnej”, 10 (1962) s. 81-100.

Sułowski Zygmunt, Ruch naturalny ludności ziemi lubelskiej w latach 1582-1900, „Folia Societatis Scientarium Lublinensis", 18 (1976) Hum. 1, s. 1-11.

Wiercieński Henryk, Próbki szperań po archiwach. Z ruchu ludności i zaludnienia na terytorium dawnego województwa lubelskiego w ciagu 3-ch ostatnich stuleci, „Rocznik Polskiego Towarzystwa Krajoznawczego", 4 (1910) s. 313-329.

\section{ZASÓB KSIĄG METRYKALNYCH W ARCHIWACH PARAFII RZYMSKOKATOLICKICH LUBELSZCZYZNY. CZĘŚĆ I}

\section{Streszczenie}

Artykuł prezentuje efekty kwerendy prowadzonej w latach 2012-2015 w 60 archiwach parafii rzymskokatolickich Lubelszczyzny. Jej celem było m.in. skatalogowanie wszystkich zachowanych ksiąg metrykalnych, w których wpisy rozpoczynają się przed grudniem 1900 r. Podobne próby podejmowano już na początku XX w., a do prekursorów w tym zakresie należał Henryk Wiercieński. Na omawianym terenie w okresie od XVI do XIX w. metryki sporządzano według trzech rodzajów formularzy. W okresie staropolskim posługiwano się formularzem trydenckim, w latach 1797-1810 formularzem austriackim, a od sierpnia $1810 \mathrm{r}$. tzw. formularzem polskim. W aneksie niniejszego studium umieszczono wykaz zachowanych ksiąg metrykalnych 7 parafii. Pozostała część materiałów zostanie opublikowana na łamach kolejnych tomów czasopisma „Archiwa Biblioteki i Muzea Kościelne”.

Słowa kluczowe: archiwum parafialne; księgi metrykalne; Lubelszczyzna; inwentaryzacja; zasób archiwalny 


\title{
THE COLLECTION OF THE REGISTER BOOKS IN THE ARCHIVES OF THE ROMAN CATHOLIC CHURCHES IN THE LUBLIN REGION. PART 1
}

\begin{abstract}
Summary
The article presents the effects of research conducted in the years 2012-2015 in 60 archives of the Roman Catholic parishes in the Lublin region. Its aim was, among others, to catalogue all the preserved register books whose entries started before December 1900 . Similar attempts were made at the beginning of the 20th century, and Henryk Wiercieński was one of the precursors in this field. In the region under investigation, register books were based on three types of forms in the period from the 16th to the 19th centuries. In the Old Polish period, a Tridentine form was used, in the years 1797-1810 - an Austrian form, and from August 1810 onwards - so-called Polish form. An annexe to the following study includes the list of the preserved register books of seven parishes. The rest of the material will be published in the subsequent volumes of the journal "Archiwa Biblioteki i Muzea Kościelne".
\end{abstract}

Keywords: a parish archive; register books; the Lublin region; inventorying; an archival collection 